\title{
Trade, Wages, and Collective Bargaining: Evidence from France
}

\author{
Juan Carluccio*, Denis Fougère and Erwan Gautier
}

Abstract: We estimate the impact of international trade on wages using data for French manufacturing firms. We instrument firm-level trade flows with firm-specific instrumental variables based on world demand and supply shocks. Both export and offshoring shocks have a positive effect on wages. Exports increase wages for all occupational categories while offshoring has heterogeneous effects. The impact of trade on wages varies across bargaining regimes. In firms with collective bargaining, the elasticity of wages with respect to exports and offshoring is higher than in firms with no collective bargaining. Wage gains associated with collective bargaining are similar across worker categories.

Keywords: exports, offshoring, firm-level wages, collective bargaining.

JEL Codes: F16, J51, E24.

\footnotetext{
*Corresponding author: Juan Carluccio, Banque de France, 46-2401 DGEI-DEMS-SAMIC, 31 Rue Croix-des-PetitsChamps, 75049 PARIS CEDEX 01. juan.carluccio@banque-france.fr.

We thank Laurent Baudry and Amelie Schiprowski for valuable research assistance. We are grateful to the Editor and one referee for very insightful suggestions that helped us to improve the paper substantially. We also thank Pierre Cahuc, Chiara Criscuolo, Bruno Decreuse, Fabrice Defever, Peter Egger, Olivier L'Haridon, François Langot, Rémy Lecat, Jakob Munch, Julien Prat, Hans-Jörg Schmerer and the participants of various conferences and seminars where previous versions of the paper were presented. The views expressed in this paper do not necessarily reflect those of the Banque de France.
} 
What is the impact of globalisation on wages? A flourishing theoretical literature highlights tradeinduced variation in firm-specific wages as a fundamental component of wage inequality, predicting heterogeneous effects across tasks, occupations and skills (see Harrison et al., 2011, for a review). This literature points to rent-sharing as a key mechanism through which trade-created revenues are transmitted to wages. In European countries, collective bargaining is the most important formal rentsharing mechanism and plays a key role in wage determination (Venn, 2009). However, empirical evidence of how collective bargaining shapes the effect of trade on wages is scarce.

In this paper we present a comprehensive empirical study of the impact of exports and offshoring on the wage levels of French manufacturing firms, testing for heterogeneous effects across occupational categories and bargaining levels.

We use a rich dataset obtained by matching several administrative sources providing firm-level information on exports and imports, balance-sheet, hourly wages by occupational category, and firmand industry-level wage agreements. The detailed trade is broken-down by product (at the HS6 level) and country or origin/destination. It allows us to overcome the potential endogeneity bias arising from unobserved shocks leading firms to simultaneously choose both trade flows and wages. We construct firm-specific instruments for exports and offshoring following the recent work by Hummels et al. (2014) (based on Autor et al., 2013). For each firm, we define a set of potential markets (productcountry pairs) based on pre-sample trade flows and use world demand and supply shocks specific to each product-country pair as exogenous shifters. The quality of our instruments requires the set of potential markets to be specific to each firm and stable over time, two conditions that are met in our data. Our results are robust to excluding markets where French firms are dominant, ensuring the exogeneity of the supply and demand shocks used for identification. The use of specific firm-level instruments for exports and offshoring allows identification of the potentially different effects of both activities on firms' wages. In our data and as in most trade datasets (e.g., Bernard et al., 2012), exporters tend to be also offshorers, which raises the need to control for export activity in order to identify the effect of offshoring and vice versa. 
Our first empirical contribution is to provide evidence on how trade shocks are transmitted to wage levels. We find that both exports and offshoring shocks have a significantly positive effect on wages, with the elasticity being higher for exports. The results are consistent with recent theories that explain the export wage premium through either rent-sharing (e.g., Egger and Kreickemeier, 2009; Amiti and Davis, 2012; Helpman et al., 2012) or differences in workforce composition (e.g., Yeaple, 2005; Verhoogen, 2008; Bustos, 2011). They are also in line with the view that access to foreign goods through overseas production lowers costs and boosts productivity, resulting in higher wages (Grossman and Rossi-Hansberg, 2008).

We then perform the analysis by occupation. Theories focusing on workforce composition predict exports increase the marginal returns to skills (e.g., by facilitating the adoption of skill-biased technologies) and thus the wages of high-skilled individuals. It suggests heterogeneous effects across occupations, being stronger for occupations that are on average high-skilled (i.e. technical and managerial). Theoretical models of offshoring also predict strong heterogeneous effects. Foreign production reduces the wages of workers whose tasks can be offshored via a substitution effect, but raises the marginal productivity and wages of workers undertaking tasks complementary to the offshored production. Our empirical results show that export shocks have a positive effect on wages with no significant differences across occupations. On the contrary, we find that offshoring shocks lead to significantly higher wages for technicians and executives, and have no impact on the wages of blue- and white-collars. These findings suggest that, on average, workers in the high-skilled occupations are complements to overseas production, while those in the relatively low-skilled ones are substitutes.

Two important messages arise. First, as predicted by theoretical models with firm heterogeneity, the dispersion in trade shocks generates between-firm dispersion in wages which also holds within occupations. Second, export and offshoring shocks prompt different changes in the production process, with the latter having strong redistribution effects across occupational categories (see Hummels et al., 2014, for similar evidence on Denmark). 
Our second contribution is to provide evidence on how the firms' bargaining regime shapes the effect of trade shocks on wages. Collective bargaining is a particularly relevant rent-sharing mechanism in France where the labour market institutions favour collective negotiations and a large share of the workforce is covered by collective wage agreements (Avouyi-Dovi et al., 2013). The French system is very close to that of other European countries (Du Caju et al., 2009); thus, our analysis sheds light on general mechanisms likely at work in other countries.

We classify firms according to whether they are covered by firm-level, industry-level or no collective wage agreements. The main finding is the following: in firms with collective bargaining, the elasticity of wages with respect to both exports and offshoring shocks is higher than in firms with no collective bargaining. These results give support to the idea that, through collective negotiations, a share of the trade-created rents is captured by the workers. They unveil an additional source of trade-induced between-firm wage dispersion that arises from the heterogeneity in bargaining regimes across firms. The data shows differences between exports and offshoring. The effect of exports is positive irrespective of the bargaining regime, and higher under firm- than industry-level bargaining. This result mimics the findings of closed economy studies showing that wages tend to be more responsive to profitability shocks under firm- than industry-level bargaining (e.g., Gürtzgen, 2009). We find a negative effect of offshoring shocks in firms without collective agreements. It suggests that, absent formal rent-sharing agreements, the productivity gains associated with offshoring accrue to the firms' shareholders. Finally, the wage gains are similar across worker categories. Collective bargaining does not appear to reduce the wage inequalities across categories associated with offshoring.

We contribute to the burgeoning empirical literature on trade and wages, which has thus far mainly analysed the impact of exports and offshoring separately (see Feenstra and Hanson, 2003 and Harrison et al., 2011 for surveys), and to a small literature focusing on the role of collective bargaining, notably Kramarz (2010) and Felbermayr et al. (2014). We complement previous works by identifying the distinct effect of both trade activities in the same firm with instrumental variables, by unveiling heterogeneous responses across occupations and by using detailed data on bargaining regimes. Our results also contribute to the literature on collective bargaining in closed economies (e.g., Dahl et al., 
2013), by using trade as exogenous shocks to identify heterogeneous effects according to the bargaining regimes.

Our paper is organised as follows. Section 1 provides a brief theoretical background. Section 2 describes the data sources and the estimating sample. Section 3 presents the empirical model and the construction of the instrumental variables. Section 4 studies how trade shocks affect firm-level wages, on average and by occupation. Section 5 focuses on the role of the bargaining regime. Section 6 concludes.

\section{Theoretical Background}

A large body of theoretical work studying the impact of trade on wages has flourished in recent years. This literature focuses on the impact of trade on wage dispersion between firms. It constitutes a major departure from traditional trade theories that placed the emphasis on wage differences between occupations and sectors. The recent theories generate a rich set of predictions linking firm-specific wages to firms' trade participation that provide the background of our empirical analysis.

The literature builds upon the seminal contribution by Melitz (2003) that features firm heterogeneity in productivity and fixed export costs. Trade liberalisation reallocates market shares towards the more productive firms and raises their profits, while it leads the least productive ones to exit. In the original Melitz model, the heterogeneity in profits and trade status of firms does not translate into wage heterogeneity because all workers are homogenous and labour markets are frictionless. Theoretical models generating wage variations between firms depart from those assumptions and can be roughly classified in two groups: 'workforce composition' and 'rent-sharing'.

The first set of papers allows for worker heterogeneity in skills while maintaining the assumption of competitive labour markets. Wages reflect marginal productivities. Firms that enter the export market adopt more skilled-intensive technologies that raise returns to skills in those firms. In equilibrium, exporters employ better workers and pay higher average wages than non-exporters. Representative 
examples of this class of models are those by Yeaple (2005) and Bustos (2011). ${ }^{1}$ The effects of offshoring are also heterogeneous across workers, and depend on how each type of worker interacts with the imported goods in the production process. Offshoring boosts the marginal productivity and demand for workers with tasks complementary to the imported goods, affecting their wages positively. It leads to wage and employment losses for workers who are substitutes to the imported goods (Feenstra and Hanson, 1999). It is generally assumed that skilled workers are complementary to offshored production.

The second group of models generates a true 'trade wage premium' since wages are above marginal productivities. Rent-sharing implies wages are an increasing function of profits and arises in the presence of labour market frictions. Models of the exporter wage premium with rent-sharing are based on fair wage considerations (Egger and Kreickemeier, 2009; Egger et al., 2013; Amiti and Davis, 2012), efficiency wages (Davis and Harrigan, 2011) or search-and-matching frictions with individual bargaining (Felbermayr et al., 2011; Helpman et al., 2012). Offshoring wage premia can also be generated through rent-sharing mechanisms because offshoring lowers costs and raises profits, creating a surplus that can be shared with workers. The 'productivity effect' of offshoring has been formalised by Grossman and Rossi-Hansberg (2008) and is in line with available evidence on the effects of imported inputs on productivity (Amiti and Konings, 2007). Amiti and Davis (2012) develop a Melitz-type model with fair wages. Sethupathy (2013) models bilateral bargaining between workers and offshoring firms.

A set of models studies collective bargaining as a particular rent-sharing mechanism, with wages determined through bargaining between firms and trade unions. The general prediction is that reductions in trade costs lead to a positive correlation between exports and wages (e.g., Naylor, 1998 and 1999, Bastos and Kreickemeier, 2009). There is an established literature modelling the wage effects of offshoring when wages are set through collective bargaining. Offshoring provides the firm with an outside option in the bargain, leading to heterogeneous wage effects across workers. When local and foreign workers are substitutes, the threat of moving production abroad constrains union

\footnotetext{
${ }^{1}$ Verhoogen (2008) highlights the role of quality upgrading, and Burstein and Vogel (2012) and Harrigan and Reshef (forthcoming) assume more productive firms use more skill-intensive technologies.
} 
wage demands, generating a negative relationship between offshoring and union wages. The opposite effect is expected when local and foreign workers are complements (Skaksen and Sorensen, 2001 and Lommerud et al., 2009).

The effect of collective bargaining on wages is the subject of an extensive literature. Of interest to our analysis is how the level of centralisation of bargaining affects wage outcomes (e.g., Calmfors and Driffill, 1988). A general prediction is that wages are more tightly linked to profits under firm-level than under more centralised bargaining levels (i.e., industry or national), because trade unions are concerned with idiosyncratic profitability shocks (see Gürtzgen, 2009 for empirical evidence). Most available evidence shows wage levels are higher under firm- than under industry-level bargaining, especially in countries with multi-level bargaining systems (e.g., Card and de la Rica, 2006; Plasman et al., 2007; Dahl et al., 2013). Another relevant issue is whether collective bargaining reduces inequalities within firms by compressing the wage distribution. The general consensus is that this is the case, as illustrated in the textbook treatment of Cahuc et al. (2014) and the empirical survey in Card et al. (2004).

\section{Data}

We match data from four administrative sources with firm-level information on imports and exports, balance-sheet data, wages, and collective wage agreements. We now describe the data sources and explain the construction of our estimating sample. Table 1 presents the data sources succinctly.

\section{[Insert Table 1]}

\subsection{Data Sources}

Trade data: The trade data come from an exhaustive administrative file collected by the French Customs. The yearly value of imports (by country of origin and product) and exports (by country of destination and product) are reported for all firms over the period 1996-2009. Trade flows are originally classified at the $\mathrm{CN} 8$-digit level (EU - Combined Nomenclature) but we aggregate them at 
the 6-digit level of the Harmonised System (HS6) to construct our instruments. We restrict our sample to imports and exports of manufactured goods by manufacturing firms. ${ }^{2}$

The theory reviewed in Section 1 points out that the effect of offshoring on wages potentially differs according to whether the imported goods complement or substitute for activities that can be undertaken within the firm. In light of this, for each firm in our sample we want to have an empirical measure of offshoring that captures the transfer abroad of production activities that were carried out (or could have been carried out) by the same firm in France. Within the firm, these goods produced with foreign labour are more likely to substitute for domestic labour. In order to construct such measure we apply the methodology developed by Feenstra and Hanson (1999) which has become standard in the offshoring literature (Biscourp and Kramarz, 2007, also apply it to French data). The idea is to include only imports of goods that are close to the final output produced by the firm. In practice, for each firm in the sample we keep only those imported goods that belong to the industry where the firm operates. ${ }^{3}$ We then sum the remaining imports flows for each firm and each year, obtaining the firm-year measure of offshoring that we use throughout the paper. ${ }^{4}$ Feenstra and Hanson (1999) and Hummels et al. (2014) label this 'narrow offshoring', but for simplicity we use the term 'offshoring' throughout. The above definition should be kept in mind when interpreting the results. As a robustness check, we provide the results obtained using total imports as a measure of offshoring in Appendix D.

Balance sheet data: The administrative BRN dataset ('Bénéfices Réels Normaux') is constructed from tax records and provides us with balance-sheet information on sales, employment, material usage, capital stock and main sector of activity at the 5-digit NAF Rev2 level (NAF = French classification of

${ }^{2}$ We exclude raw materials (HS01-15, 23, 25-27, 31 and 41) e.g., 'Vegetable products', 'Mineral products', 'Fertilizers' and 'Works of art, collector's pieces and antiques', and 'Services' (HS97-99). Excluded trade flows are about $5 \%$ of the total value of French imports and exports.

${ }^{3}$ More specifically, we use a concordance table provided by Eurostat (from the RAMON Metadata Server) to map HS6 codes into the European product classification CPA2008. The CPA2008 is identical to the French product classification CPFRev2. Finally, we use concordance tables from INSEE to map CPFRev2 product codes into NAFRev2 4-digit industry codes (see 'Balance sheet data'). With this classification in hand, for each firm we drop all imports of HS6 codes that do not map into their NAF code.

${ }^{4}$ To have a better understanding of this measure, take for example the HS6 code 701932 'Thin sheets (voiles) of Glass Fibres'. When this code is imported by firms in the NAF code 2314 'Manufacture of Glass Fibers' we keep these imports in our measure of offshoring for those firms. When the same code is imported by the firms in the NAF code 2399 'Manufacture of other non-metallic mineral products' we exclude it from the offshoring measure for these firms. 
economic activities, the first four digits of which are identical to the NACE Rev2 classification). It includes over $60 \%$ of French firms and accounts for over $90 \%$ of the value of trade flows in the Customs dataset. We use the BRN data to estimate firm-level total factor productivity (TFP) as the residual of a two-factor (capital and labour) Cobb-Douglas production function, separately for each 2digit industry using data on 1,026,147 observations over the period 1994-2009. Our preferred measure uses the Levinsohn and Petrin (2003) method.

Wage data: The administrative dataset DADS ('Déclarations Annuelles de Données Sociales') comes from firms' social security records. For the period 2005-2009 and for every plant with at least one employee, it provides the number of workers and hourly wages, both overall and for each of the following occupations: 'Administrative and commercial executives (including engineers)', 'Technicians and supervisors', 'White-collar employees', 'Production (blue collar) workers'. Occupational categories are defined on the 'Nomenclature des professions et catégories socioprofessionnelles' (PCS). ${ }^{5}$ The number of temporary contracts at the firm that we use as a control also comes from DADS.

Wage agreements data: We use comprehensive information on wage agreements signed at the firmand industry- levels, for each firm and year in the period 1994-2009. The data comes from the French Ministry of Labour and it is exhaustive, given the legal obligation to report on all concluded firm-level agreements. Variables included are the date and topics of the agreements. Agreements can cover a variety of topics other than wages (see Appendix Table A1 for details). We focus on firm-level agreements dealing with wages because they are more likely to affect the wage-setting process and also because wages are the most frequent topic dealt with (over 70\%). We also have information on wage agreements at the industry-level for the 300 largest industries (branches in French) for 19942009, constructed by Avouyi-Dovi et al. (2013).

\footnotetext{
${ }^{5}$ Although this variable refers to occupations, it has often been used to proxy for the workers' skill level (e.g., Cahuc et al., 2006).
} 


\subsection{Estimating Sample}

Our estimating sample is obtained by matching the above datasets using a common firm identifier. ${ }^{6}$ We clean the data in the following way. We drop outliers of hourly wages (overall and by occupation) and of sales per employee. ${ }^{7}$ The data show the existence of a substantial share of firms with marginal trade activity. We normalise export and offshoring values by total sales, and look at their distribution in our sample. Both distributions exhibit a large mass of observations with very low values: the $5^{\text {th }}$ percentile of the export-to-sales ratio is $0.2 \%$, whereas the median is $15 \%(0.03 \%$ and $3 \%$ for offshoring). Firms with negligible exposure to international trade can contaminate our results as potential outliers. In light of this we drop firm-year observations for which the export-to-sales or the offshoring-to-sales ratio are below the $5^{\text {th }}$ percentile of the distribution. ${ }^{8}$

We include firms only in the years in which they both import and export, a restriction required for the implementation of our IV strategy (defined below). Hence, our study focuses on how changes in the intensive margin of trade affect wages. Our results need to be interpreted as informative of how wages are affected by shocks allowing firms to deepen their trade activities conditional on the firm being exporter and importer. Obtaining results applying to all firms would require accounting for the endogeneity of entry into the export and import markets (i.e., the 'extensive margin'). Such strategy would require at least one instrumental variable that predicts the change in trade status of firms. Such instrument is difficult to obtain in absence of a major policy change. Furthermore, identification of the extensive margin is made difficult by the limited variation in trade status over time. Firms that both export and import tend to do it continuously over the period 1996-2009, with a mass of firms that never enter foreign markets in our sample (Appendix Figure B2).

Our estimating sample contains 23,269 observations corresponding to 8,123 firms and accounts for over two thirds of the total value of both exports and imports of the Customs dataset. The sample period is 2005-2009 because our dependent variables (i.e. firm-level hourly wages) are only available

\footnotetext{
${ }^{6}$ We provide online the programmes that allow the replication of our results, along with details on how to access the confidential data used in the paper.

${ }^{7}$ We define outliers as observations below the $1^{\text {st }}$ percentile or above the $99^{\text {th }}$ percentile of the distribution.

${ }^{8}$ In Appendix Table B1 we report robustness checks using different thresholds of trade intensity (instead of 5\% and including no trimming). We obtain similar results.
} 
for those years (Table 1). It exhibits large between-firm variation in both trade and wages, but limited within-firm variability. Identification will mainly come from differences between firms rather than from variations over time for a given firm. This feature of the data is not the consequence of the relatively short sample period: very similar patterns emerge over the longer period 1996-2009 (Appendix Table B3). Hauptmann and Schmerer (2013) also raise a similar issue for German firms.

Table 2 reports descriptive statistics based on our estimating sample. Exports and offshoring increased steadily from 2005 to 2008 , before dropping sharply in 2009 . The hourly wage of blue- and whitecollar workers increased on average by a little less than $3 \%$ whereas the hourly wage of supervisors and executives slightly dropped in 2009 . We will test whether our results are robust to the Great Recession by reporting results excluding the year 2009 as robustness checks.

\section{[Insert Table 2]}

\section{Empirical Model}

This section describes the empirical model and the instrumentation strategy.

\subsection{Wage Equation}

Our baseline wage equation is the following:

$$
\ln w_{i t}=\beta_{\exp } \ln \exp _{i t}+\beta_{o f f} \ln o f f_{i t}+\beta_{x} x_{i t}+\alpha_{i}{ }^{w}+\lambda_{t}{ }^{w}+\varepsilon_{i t}
$$

where for the firm $i$ in year $t \ln w_{i t}$ is the $\log$ net hourly wage, $\ln \exp _{i t}$ the $\log$ exports and $\ln o f f_{i t}$ the $\log$ offshoring. $x_{i t}$ is a vector of covariates including the local unemployment rate and firm-level controls in year $t$ (number of employees, TFP, domestic sales, proportion of temporary workers, share of skilled workers and capital-labour ratio). $\alpha_{i}{ }^{w}$ is a random firm-specific effect, $\lambda_{t}{ }^{w}$ is a year dummy (common to all firms) and $\varepsilon_{i t}$ is an i.i.d. random term (white noise) with mean 0 and variance $\sigma_{\varepsilon}{ }^{2}$. Slope parameters $\beta_{\text {exp }}$ and $\beta_{\text {off }}$ are interpreted as elasticities of wages with respect to firm exports and offshoring. 
The identification strategy will mainly exploit between-firm variation, consistently with trade theories of firm heterogeneity. To control for observable firm heterogeneity we add disaggregate industry (4digit)-level dummies and adopt a Mundlak's formulation of the linear panel data model, by adding the firm's average TFP and the firm's average capital/labour ratio to the list of regressors. Since all these supplementary variables are time-invariant, we assume a random firm-specific effect $\alpha_{i}{ }^{w}$. The Mundlak formulation allows for possible correlations between the time-varying explanatory variables and the firm-specific fixed effects.

The theoretical works reviewed in Section 1 predict the relationship between trade and wages can be heterogeneous according to worker categories and bargaining regimes. We will estimate equation (1) using average wages, then separately by occupational category and by bargaining regime.

\subsection{Instrumentation Strategy}

We face a potential endogeneity issue: unobservable shocks might simultaneously affect wages, export and offshoring flows in a given firm and a given year, making OLS estimates of $\beta_{\text {exp }}$ and $\beta_{\text {imp }}$ inconsistent. To reduce these potential biases we use instrumental variables that reflect exogenous shocks to the profitability of exporting and offshoring and are uncorrelated with firm-level wagesetting. A recent strand of the literature shows such instruments can be constructed using demand and supply shocks from the rest of the world (e.g., Autor et al., 2013; Hummels et al., 2014). The underlying idea is the following. A shock to the demand of a given product $p$ in a given country $c$ would translate into higher imports into country $c$ of this particular product $p$. French firms exporting the product $p$ to country $c$ would raise their exports to that country. Similarly, an increase in world exports of product $p$ by country $c$ reflects an increase in the competitiveness of country $c$ for the product $p$ (which can be due to an exogenous variation in productivity, costs or product quality in country $c$ ). French firms importing product $p$ from country $c$ would respond to this shock by increasing their imports of product $p$ from the country $c$. Exogeneity is ensured by the fact that demand and supply shocks in foreign locations are independent of French firms' wage determination.

World demand $W D_{i t}$ and world supply $W S_{i t}$ addressed to firm $i$ in year $t$ are: 


$$
W D_{i t}=\sum_{c, p} s_{i c p} W D_{c p t} \quad W S_{i t}=\sum_{c, p} s_{i c p} W S_{c p t}
$$

where $W D_{c p t}$ and $W S_{c p t}$ are respectively world demand and supply for a product-country pair at time $t$ computed using data at the 6-digit level of the Harmonised System HS from the BACI dataset constructed by CEPII. ${ }^{9}$ We calculate the firm-specific shares $\mathrm{s}_{\text {icp }}$ of each pair (product $p$, country $c$ ) in total exports (respectively, offshoring) using average shares of the products actually exported (respectively, imported) in the period 1996-2004. We choose to use pre-samples values to reduce endogeneity concerns. For the few firms entering foreign markets within our sample period, we calculate these shares for the first year in which the firm reports positive trade (and we include the firm in the sample from its second year onwards)..$^{10}$

The quality and the precision of our instrumentation strategy depend on whether the set of productcountry pairs entering $W D_{i t}$ and $W S_{i t}$ is stable over time. Over the period 1996-2009, firm-level export and offshoring flows tend to be concentrated in one main (HS6) product and one country. The two main products represent on average $83 \%$ of firm-level exports, and the two main product-country pairs account for 57\% (90\% and $80 \%$ for offshoring respectively, see Appendix Table C1). Furthermore, the average firm changes its main product only once during the sample period (often replaced with a very close product). The set of products and countries that constitute the firms' potential markets is quite stable over time. Our instrumentation strategy that relies on pre-sample trade composition to compute firm-specific world demand and supply is satisfactory.

A second concern is whether the instruments provide enough between-firm variation for identification. If the set of product-country pairs is specific to each firm, world demand and supply shocks will affect each firm differently. To look into this feature of the data, for every firm in the sample we identify the two most important product-country pairs, defined as those that account for the highest share in total exports. We then compute the frequency of firms having the same two most important product-country

\footnotetext{
${ }^{9}$ The BACI dataset is constructed using bilateral trade data at HS 6-digit level from COMTRADE. It can be downloaded at http://www.cepii.fr/CEPII/en/bdd_modele/presentation.asp?id=1 (last accessed: 11 December 2014)

${ }^{10}$ As a robustness check, we have also computed instruments using shares calculated over the period 1996-2009 as in Berman et al. (2012). Results are very similar.
} 
pairs (we do the same for offshoring). The median is 2 firms for exports and 3 firms for offshoring (see Appendix Table $\mathrm{C} 2$ for further details). The set of product-country pairs is quite specific to each firm. ${ }^{11}$

Our instrumentation equation is:

$$
\begin{aligned}
& \ln \exp _{i t}=\gamma_{W D}^{\text {exp }} \ln W D_{i t}+\gamma_{W S}^{\text {exp }} \ln W S_{i t}+\gamma_{\text {exp }} x_{i t}+\alpha_{i}^{\text {exp }}+\lambda_{t}^{\text {exp }}+\epsilon_{i t} \\
& \ln o f f_{i t}=\gamma_{W D}^{o f f} \ln W D_{i t}+\gamma_{W S}^{\text {off }} \ln W S_{i t}+\gamma_{o f f} x_{i t}+\alpha_{i}^{\text {off }}+\lambda_{t}^{\text {off }}+\zeta_{i t}
\end{aligned}
$$

where $x_{i t}$ is a vector of firm-level controls identical to the one used for the estimation of (1). $\lambda_{t}{ }^{\exp }$ and $\lambda_{t}{ }^{\text {off }}$ are year dummies (common to all firms), and $\epsilon_{i t}$ and $\zeta_{i t}$ are i.i.d. random terms (white noises) with mean 0 and variances $\sigma_{\epsilon}{ }^{2}$ and $\sigma_{\zeta}^{2}$, respectively. The estimation of (2.A) and (2.B) yield consistent estimates of $\ln \exp _{i t}$ and $\ln o f f_{i t}$ which are denoted $\ln \widehat{\exp } p_{i t}$ and $\ln \widehat{o f} f_{i t}{ }^{12}$

\section{[Insert Table 3]}

Table 3 reports the results. They constitute the first-stage regressions of our empirical strategy. Results are reported with and without the vector of controls $x_{i t}$, but including firm-specific fixed effects and year dummies in all cases. Robust standard errors are clustered at the firm level. As expected, world demand (respectively, supply) has a positive and statistically significant effect on exports (respectively, offshoring). The values of the F-statistics indicate that these instruments are not weak. The estimates show that size, productivity, and capital- and skill-intensity are associated with larger values of firm-level offshoring and exports, consistent with firm heterogeneity theories of international trade. Their inclusion reduces the magnitude of the coefficient associated with the instruments, without affecting their significance levels.

\footnotetext{
${ }^{11}$ A similar issue can arise if world demand and supply shocks are highly correlated between countries. This could happen if shocks in large countries drive most of the variability in world demand and supply. As robustness check, we ran equations (2.A) and (2.B) excluding France's three largest trade partners (China, Germany and the United States) which represent about 30\% of total French exports and imports. We obtain similar results (Appendix Table C3).

${ }_{12}$ We have also tested exchange rates as possible instruments but they were found to have a small or even insignificant impact on exports and imports (results are reported in Appendix Table C4). This is due to the large share of French trade within the Euro area (about 50\%), implying a small variability in average exchange rates. Moreover, this instrument varies only with the country and time dimensions.
} 
The validity of the above results relies on the exogeneity of world demand and supply shocks. Shocks to French firms can trigger demand and supply responses in markets where French firms have a large market share, challenging the exogeneity of $W D_{i t}$ and $W S_{i t}$. For robustness we use the BACI data to compute the market shares of French firms in each product-country-year cell, for exports and for offshoring. We then run equations (2.A) and (2.B) dropping product-country-year observations for which the French market shares are over $10 \%, 15 \%$, or $20 \%$, obtaining very similar results (see Appendix Table C5).

\section{How Does Trade Affect Wage Levels?}

In this section we study the impact of international trade on firm-level wages. We start by looking at average firm-level wages, and we then examine heterogeneity across occupations.

\subsection{Results on Average Firm-level Wages}

As discussed in Section 1, the first message that comes out of recent theoretical works is that firmlevel wages should be affected by firm-level trade. Most theoretical models predict exports should have a positive effect, irrespective of the particular underlying channel (i.e. composition or rentsharing). The effect of offshoring is a priori ambiguous because it results from the combination of two opposing forces. Offshoring might boost productivity and raise profits, positively affecting wages (the 'productivity effect'). However, offshoring can replace tasks previously carried out by domestic workers, leading to lower wages for those workers.

In Figure 1 we pool all observations in our sample and plot the firm-level average hourly wages (in euros) as a function of percentiles of the distribution of exports and offshoring per employee. Both variables are positively correlated with firm-level wages. At the aggregate level and without any controls, the positive effect of offshoring on wages seems to dominate.

\section{[Insert Figure 1]}

We now proceed to a formal econometric analysis. In Table 4 we report the results obtained for different specifications of equation (1). The dependent variable is the log hourly net wage rate in firm $i$ 
and year $t$. Columns (1) and (3) report OLS estimates, respectively without and with firm-level controls. Columns (2) and (4) report the second stage of OLS-IV estimates, where exports and offshoring (in logs) are instrumented through the first-stage regressions reported in Table 3. Robust standard errors are clustered at the firm level.

The main finding is that both exports and offshoring have a highly significant positive effect on wages. This result is in line with the theoretical prediction concerning the effects of exports on average wages, and suggests the positive effects of offshoring dominate the negative ones (as was already suggested by Figure 1). The introduction of firm-level controls substantially decreases the size of both elasticities, from 0.02 to 0.01 in the case of exports and from 0.01 to 0.004 in the case of offshoring. Hummels et al. (2014) argue that including firm-level performance covariates controls for the indirect impact of trade on wages through enhanced productivity. Under this view, columns (3) and (4) provide the effects of exports and offshoring net of this 'productivity effect'. Even when adding firm-level controls we find a positive and significant impact of both trade activities on wages. ${ }^{13}$ These average results might mask heterogeneity across worker categories. We explore such hypothesis in the next subsection.

\section{[Insert Table 4]}

\subsection{Results by Occupation}

A second message arising from the literature survey is that the impact of trade on wages can potentially vary with the workers' occupation and skills. Models based on 'workforce composition' predict export shocks should lead to the adoption of skill-biased technology and increase the marginal returns to skills. A higher elasticity in the case of high-skilled occupations (i.e., technicians and executives) would be in line with the idea that export shocks increase the marginal productivity of high-skilled workers and their wages. The impact of offshoring is potentially quite different. The theory suggests it should also be heterogeneous across workers, being positive for those who are complements to the imported goods, and negative for those who are substitutes. Our hypothesis is that

\footnotetext{
${ }^{13}$ Results are robust to the exclusion of the year 2009 (Appendix Table D1) and to using total imports instead of 'offshoring' (Appendix Table D2).
} 
high-skilled occupations, such as engineers and executives, are more likely to be complements to offshoring, whereas low-skilled occupations, mainly production workers, are more likely to be substitutes.

\section{[Insert Figure 2]}

In Figure 2 we repeat the analysis conducted in Figure 1, but this time separately for each of the four occupational categories. It is clear that the positive correlation between exports and wages exists for all occupations. The relationship between offshoring and wages seems to be much steeper for technicians and executives, which provides a motivation for running the basic wage regressions of equation (1) separately by occupational categories.

\section{[Insert Table 5]}

Table 5 presents the results. The dependent variable is the log hourly average net wage rate of occupation $o$ in firm $i$ and year $t$. All regressions include the full set of firm-level covariates.

The results are striking. The elasticity of wages with respect to exports is similar for all occupations and for both estimation techniques (about 0.005 ). The results do not show evidence of redistribution effects across groups of workers due to foreign demand shocks. The offshoring results are quite different: offshoring has no impact on the average wage of blue- and white-collars but leads to significantly higher wages for technicians (elasticity of 0.004) and executives (elasticity of 0.007 ). As we have argued, it is reasonable to expect these occupations to be more likely to be complements to offshoring. The results in Table 5 thus suggest that a better access to foreign goods through offshoring generates a substantial reorganisation of home production, which on average benefits the most skilled occupations. ${ }^{14}$ Unlike previous studies (e.g., Hummels et al 2014) we do not find negative effects on the low-skilled occupations. One possible explanation that we explore in the next section might be related to the role of wage bargaining institutions in affecting wage outcomes.

Our estimates show trade shocks generate between-firm dispersion in wages, both on average and within occupations. One main theoretical explanation of such a link is the following: trade generates

\footnotetext{
${ }^{14}$ Results are also robust to the exclusion of the year 2009 (Appendix Table D3) and to considering total imports instead of 'offshoring' (Appendix Table D4).
} 
dispersion in firm revenues which are then transmitted to wages via a rent-sharing mechanism. Collective bargaining is a rent-sharing mechanism which we believe to be particularly relevant in France (as in many European countries).

\section{How Does Collective Bargaining Shape the Effect of Trade on Wages?}

The institutional features of collective wage bargaining in France are very similar to that of other European countries (Du Caju et al., 2009). Wages can be set at three different levels: (i) at the national level, a binding minimum wage is set by the government; (ii) at the industry-level, employers' organisations and unions bargain on wage scales by occupational categories; (iii) at the firm level, employers and unions bargain on wage increases that can be uniform for all employees or specific to occupational categories. There is a strict hierarchy between the different levels of wage bargaining: a collective agreement must set forth, broaden or enhance an agreement which has been previously signed at a higher bargaining level. Industry-level wage agreements cover around $75 \%$ the firms in our sample and firm-level wage agreements cover about $20 \%$ (Table 2).

In France, the occurrence of wage agreements is persistent over time within firms. To study whether the effect of trade on wages differs according to the wage bargaining regime we group firms in three different regimes: 1) firms not covered by any type of wage agreement (or covered only very infrequently), 2) firms frequently covered only by industry-level agreements, and 3) firms that frequently sign firm-level agreements. We consider that a firm is 'frequently' covered by an agreement of either type if it reports agreements in over $20 \%$ of the years it appears in the sample ( $20 \%$ is the sample average frequency).

We estimate equation (1) separately for firms in each regime, first by considering average firm-level wages, then for each occupational category. ${ }^{15}$

5.1 Results by Bargaining Level: Average Firm-level Wages

\footnotetext{
${ }^{15}$ Regimes are assumed to be exogenous since there is no instrument available.
} 
The rent-sharing hypothesis leads us to expect a higher elasticity in firms with collective bargaining, indicating a stronger transmission of trade shocks to wages. Table 6 presents the results. To save space we report only the OLS-IV estimates, where exports and offshoring are instrumented through the firststage regressions reported in Table 3.

\section{[Insert Table 6]}

The main message of the table is the following: in firms with collective bargaining the elasticity of wages with respect to both exports and offshoring shocks is higher than in firms with no collective bargaining (i.e., comparing across columns). It provides support to the idea that, through collective agreements, firms share the trade-created rents with workers in the form of higher wages. One important consequence is that the heterogeneity in bargaining regimes (Table 2) adds an additional source of wage dispersion between firms.

Interestingly, the effect of exports is estimated to be highest under firm-level bargaining ( 0.010 versus 0.015 with firm-level agreements). The theoretical survey of Section 1 tells us that the elasticity of wages to profitability shocks should be higher the more decentralised the bargaining level: wages are more tied to profits under firm- than industry-level bargaining. Our results, by using exports shocks as measures of exogenous demand shocks, contribute to the closed economy literature that has mainly focused on comparing wage levels across bargaining regimes (e.g., Card and de la Rica, 2006; Plasman et al., 2007; Dahl et al., 2013).

A second interesting result concerns offshoring. In Table 4 of Section 4 we found that, pooling all firms irrespectively of their bargaining regimes, offshoring affects wages positively. The comparison with Table 6 shows that the average effect arises from the combination of heterogeneous responses according to the bargaining regime. Wages are negatively affected by offshoring shocks in firms without collective agreements: the elasticity is -0.001 for $2005-2009$ and -0.004 when we exclude the crisis year 2009. Wages are positively affected in firms covered by industry-level agreements (elasticity 0.004). By affecting their marginal productivity differently, offshoring leads to wage losses for workers who are substitutes to foreign production and to wage gains for those who are complements. With rent-sharing, workers extract a larger share of the surplus created by offshoring 
adding a positive effect on wages. This mechanism can lead to an overall positive effect of offshoring under collective bargaining.

Overall our estimates support the idea that bargaining results in wage gains. One open question is whether such gains accrue to all worker categories or they are reaped by some occupations, for instance because of differences in bargaining power.

\subsection{Results by Bargaining Level and by Occupation}

Table 7 presents estimates of equation (1) separately for firms in each regime and for each occupational category. A key general result is that the elasticity of wages with respect to trade shocks is higher under collective bargaining for all categories.

\section{[Insert Table 7]}

The regressions by occupation confirm that the export premium is largest under firm-level bargaining. In particular, for blue-collar workers, the elasticity of wages to export shocks goes from 0.004 without collective bargaining, to 0.011 when there is a firm-level wage agreement. This difference is broadly similar for other worker categories (with the exception of white-collar workers for which the gains are zero).

Our results also reveal interesting patterns concerning offshoring. For the low-skilled occupations (i.e., blue- and white-collars) the effect of offshoring on wages is negative in firms with no collective agreements (being stronger and more significant for 2005-2008), and zero or slightly positive in firms with collective agreements. For the high-skilled occupations (i.e., technicians and executives) it goes from zero to positive. Quantitatively, the difference in the elasticity across regimes is similar for all categories (around 0.004 points). Collective bargaining does not appear to reduce the wage differences across occupations arising from offshoring shocks, but rather to shift wages up for all worker types. ${ }^{16}$

For robustness, we looked at whether the results are driven by agreements on wages and not by agreements on other topics. We find that the effect of exports is higher in firms that frequently bargain

\footnotetext{
${ }^{16}$ Similar results are obtained when we replace « offshoring » by « total imports » (Appendix Table D5).
} 
on any topic, but that such result is driven mainly by the existence of wage agreements (see Appendix Table D6). ${ }^{17}$

\section{Conclusion}

In this paper we study how trade affect firm-level wage levels using rich data for French manufacturing firms. We provide results on the effect of exports and offshoring shocks on average wages, analysing heterogeneous effects across occupations and bargaining regimes. We use our detailed trade data to construct firm-specific instrumental variables based on world demand and supply shocks. This strategy allows us to overcome potential endogeneity biases arising from unobservable shocks leading firms to adjust wages and trade flows simultaneously.

We first focus on the following question 'How does trade affect wage levels?' We find that both exports and offshoring have a positive impact on average wages, with the elasticity being higher for export (0.010) than for offshoring (0.004). This result is in line with the theoretical predictions of models of the exporter wage premium and suggests the positive effects of offshoring (e.g., through enhanced productivity) dominate the negative ones related to the substitution of domestic labour.

We then study whether there is heterogeneity according to occupational categories. The elasticity of wages to export shocks is similar across all worker categories (about 0.005). The impact of offshoring varies across worker types: it is close to zero for blue- and white-collars and positive and significant for technicians and executives (with elasticities of 0.004 and 0.007 respectively). It provides support to the hypothesis that unskilled workers tend to be substitutes to offshoring and skilled ones to be complements.

We conclude with an analysis of whether collective bargaining shapes the transmission of trade shocks to wages. We find that the elasticity of wages to both exports and offshoring shocks is higher in firms with collective bargaining than in firms with no collective bargaining. The effect of exports is higher under firm- than under industry-level bargaining (elasticities are 0.015 with firm-level agreements and

\footnotetext{
${ }^{17}$ There is no difference of the effect of offshoring on wages with or without firm-level agreements. The main difference comes from being or not covered by collective bargaining (i.e., firm- or industry-level agreements) as shown above.
} 
0.010 without). Concerning offshoring, the estimates shows a negative impact in firms without collective agreements and a positive impact in firms covered by industry-level agreements. As theoretical models predict, collective agreements shift trade-created rents to workers in the form of higher wages. The wage gains associated with collective bargaining are found to be similar across occupations.

Overall, our results support the predictions of firm heterogeneity models stating that trade generates between-firm dispersion in wages. Furthermore, such between-firm dispersion is enhanced by the heterogeneity in bargaining regimes across firms, generating heterogeneous transmission of trade shocks to wages.

\section{Authors' Affiliations:}

Juan Carluccio: Banque de France and University of Surrey

Denis Fougère: CNRS, CREST, LIEPP (Sciences Po, Paris), CEPR, IZA and Banque de France.

Erwan Gautier: LEMNA-TEPP, Université de Nantes and Banque de France. 


\section{References}

Amiti M. and Davis D. R. (2012). 'Trade, firms, and wages: theory and evidence', The Review of Economic Studies, vol. 79(1), pp. 1-36.

Amiti M., and Konings J. (2007). ‘Trade liberalization, intermediate inputs, and productivity: evidence from Indonesia', American Economic Review, vol. 97(5), pp. 1611-1638.

Autor D., Dorn D., and Hanson G.H. (2013). 'The China syndrome: local market effects of import competition in the U.S.', American Economic Review, vol. 103(6), pp. 2121-2168.

Avouyi-Dovi S., Fougère D., and Gautier E. (2013). 'Wage rigidity, collective bargaining and the minimum wage: evidence from French agreement data', The Review of Economics and Statistics, vol. 95(4), pp. 1337-1351.

Bastos P., and Kreickemeier U. (2009). 'Unions, competition and international trade in general equilibrium', Journal of International Economics, vol. 79 (2), pp. 238-247.

Berman N., Berthou, A., and Hericourt, J. (2012). 'Export dynamics and sales at home', CEPR Discussion Paper No 8684

Bernard, A., Jensen, B. Redding, S. and Schott, P. (2012), 'The empirics of firm heterogeneity and international trade', Annual Review of Economics, vol. 4, pp. 283-313.

Biscourp, P. and Kramarz, F. (2007). 'Employment, skill structure and international trade: firm-level evidence for France', Journal of International Economics, vol. 72(1), pp. 22-51.

Burstein A., and Vogel J. (2012). 'International trade, technology, and the skill premium', Working Paper, Columbia University.

Bustos P. (2011). 'Trade liberalization, exports and technology upgrading: evidence on the impact of MERCOSUR on Argentinean firms', American Economic Review, vol. 101 (1), 2011, pp. 304-340.

Cahuc P., Postel-Vinay F., and Robin J.-M. (2006). 'Wage bargaining with on-the-job search: theory and evidence', Econometrica, vol. 74(2), 323-64. 
Cahuc P., Carcillo, S. and Zylberberg A. (2014). Labor Economics, Second Edition, Cambridge: MIT Press.

Calmfors L., and Driffill J. (1988). 'Bargaining structure, corporatism, and macroeconomic performance', Economic Policy, vol. 6, pp. 14-61.

Card D., Lemieux T., and Riddell W.C. (2004). 'Unions and wage inequality', Journal of Labor Research, 25, vol. 4, pp. 519-559.

Card D., and de la Rica S. (2006), 'Firm-level contracting and the structure of wages in Spain', Industrial and Labor Relations Review, vol. 59, pp. 573-93.

Dahl C. M., Le Maire D., and Munch J. (2013). 'Wage dispersion and decentralization of wage bargaining', Journal of Labor Economics, vol. 31, pp. 501-533.

Davis D. R., and Harrigan J. (2011). 'Good jobs, bad jobs, and trade liberalization', Journal of International Economics, vol. 84(1). pp. 26-36.

Du Caju P., Gautier E., Momferatou D. and Ward-Warmedinger M. (2009), 'Institutional features of wage bargaining in 23 European countries, the US and Japan', Ekonomia, vol. 12(2). pp. 57-108.

Egger, H., Egger, P. and Kreickemeier, U. (2013). 'Trade, profits, and wages', European Economic Review, vol. 64(C). pp. 332-350.

Egger H., and Kreickemeier U. (2009). 'Firm heterogeneity and the labor market effects of trade liberalization', International Economic Review, vol. 50(1). pp. 187-216.

Feenstra R. C. and Hanson G.H. (1999). 'The impact of outsourcing and high-technology capital on wages: estimates for the U.S., 1972-1990', The Quarterly Journal of Economics, vol. 114(3). pp. 907940.

Feenstra R. C. and Hanson G.H. (2003) 'Global production sharing and rising inequality: a survey of trade and wages', in (E. K. Choi and J. Harrigan eds), Handbook of International Trade, pp. 146-85, Malden, MA: Blackwell Publishing. 
Felbermayr G., Prat J., and Schmerer H.-J. (2011). 'Globalization and labor market outcomes: wage bargaining, search frictions, and firm heterogeneity', Journal of Economic Theory, vol. 146(1), pp. 3973.

Felbermayr G., Hauptmann A. and Schmerer, H. J. (2014). 'International trade and collective bargaining outcomes: evidence from German employer-employee data', Scandinavian Journal of Economics, vol. 116(3), pp. 820-837.

Grossman G. M., and Rossi-Hansberg E. (2008). 'Trading tasks: a simple theory of offshoring', American Economic Review, vol. 98(5), pp. 1978-97.

Gürtzgen N. (2009). 'Rent-sharing and collective bargaining coverage - evidence from linked employer-employee data', Scandinavian Journal of Economics, vol. 111, pp. 323-349.

Harrigan J., and Reshef A., forthcoming 'skill biased heterogeneous firms, trade liberalization and the skill premium', Canadian Journal of Economics.

Harrison A., McLaren J., and McMillan M. (2011). 'Trade and inequality', Annual Review of Economics, vol. 3, pp. 261-89.

Hauptman A. and Schmerer H. J. (2013). 'Do exporters pay fair wage premiums?' Economics Letters, vol. 121(2), pp. 179-182.

Helpman E., Itskhoki O., Muendler M.-A., and Redding S. (2012). 'Trade and inequality: from theory to estimation', NBER Working Paper 17991.

Hummels D., Jørgensen R., Munch J. R. and Xiang C. (2014). 'The wage effects of offshoring: evidence from Danish matched worker-firm data', American Economic Review, vol. 104(6), pp. 15971629.

Kramarz F. (2010). 'Offshoring, wages, and employment: evidence from data matching imports, firms, and workers', Working Paper, CREST.

Levinsohn J. and Petrin A. (2003). 'Estimating production functions using inputs to control for unobservables', Review of Economic Studies, vol. 70(2), pp. 317-341. 
Lommerud K. E., Meland F. and Straume O. R. (2009). 'Can deunionization lead to international outsourcing?', Journal of International Economics, vol. 77(1), pp. 109-119.

Melitz M. J. (2003). 'The impact of trade on intra-industry reallocations and aggregate industry productivity', Econometrica, vol. 71(6), pp. 1695-1725.

Naylor R. (1998). 'International trade and economic integration when labour markets are generally unionised', European Economic Review, vol. 42(7), pp. 1251-1267.

Naylor R. (1999). 'Union wage strategies and international trade', Economic Journal, vol. 109(452), pp. 102-125.

Plasman R., Rusinek M. and Rycx F. (2007). 'Wages and the bargaining regime under multi-level bargaining: Belgium, Denmark and Spain', European Journal of Industrial Relations, vol. 13(2), pp. 161-180.

Sethupathy G. (2013). 'Offshoring, wages, and employment: theory and evidence', European Economic Review, vol. 62, pp. 73-97.

Skaksen J. R., and Sorensen M. Y. (2001). 'Should trade unions appreciate foreign direct investment?' Journal of International Economics, vol. 55(2), pp. 379-390.

Venn D. (2009). 'Legislation, collective bargaining and enforcement: updating the OECD employment protection indicators', Working Paper OECD N 89.

Verhoogen E. A. (2008). 'Trade, quality upgrading, and wage inequality in the Mexican manufacturing sector', The Quarterly Journal of Economics, vol. 123(2), pp. 489-530.

Yeaple S. R. (2005). 'A simple model of firm heterogeneity, international trade, and wages', Journal of International Economics, vol. 65(1), pp. 1-20. 
Name (source) Period $\quad$ Main variables

DADS - firm level

(INSEE)

2005-2009

'Douanes'

(French Customs)

Firm-level agreements

(Ministry of Labour)

Industry-level agreements

(Avouyi-Dovi et al.,2013)

BRN

(INSEE)

\section{BACI}

(CEPII)

1996-2009
- Average hourly wages by occupation (blue collar, white collar, technicians and executives)

- Total hours worked by occupation

- $\quad \mathrm{Nr}$ of employees with a temporary contract

Firm-level flows of exports and imports (in euros) collected at the product level (HS 6) and by country of destination or origin

Dummy variables equal to 1 if there is an agreement in a given 1994-2009 firm in a given year, 0 otherwise. Main topics of the agreement (wages, union rights...)

Dummy variable equal to 1 if there is a wage agreement in a 1994-2009 given industry in a given year, 0 otherwise. Cover about 300 of the largest industries ('branches').

Firms' detailed balance sheets

1996-2009 - Main variables: sales, nr of employees, materials...

- Used to construct TFP estimates

Flows of exports (supply) and imports (demand) by country and at the product level (by year, for all countries) 
Table 2: Descriptive Statistics on Trade and Wages

\begin{tabular}{lccccc}
\hline Year & 2005 & 2006 & 2007 & 2008 & 2009 \\
Trade (in millions Euros) & & & & & \\
- Exports & $72,184.8$ & $72,937.9$ & $70,521.6$ & $72,209.2$ & $65,105.1$ \\
- Offshoring & $21,655.8$ & $19,946.5$ & $20,330.7$ & $19,699.5$ & $20,340.2$ \\
- Total imports & $47,655.1$ & $47,981.9$ & $48,765.3$ & $47,648.9$ & $41,479.3$ \\
Average hourly wage (in Euros) & & & & & \\
- All workers & 15.48 & 15.81 & 16.28 & 16.82 & 17.04 \\
- Blue-collar workers & 11.75 & 12.07 & 12.46 & 12.91 & 13.29 \\
- White-collar workers & 12.64 & 12.94 & 13.38 & 13.90 & 14.38 \\
- Technicians and supervisors & 17.13 & 17.37 & 17.90 & 18.35 & 18.12 \\
- Executives & 29.58 & 29.96 & 30.66 & 31.84 & 30.44 \\
Coverage of wage agreements (in \%) & & & & & \\
Firm wage agreement & 17.0 & 18.4 & 20.7 & 22.7 & 20.1 \\
Industry wage agreement & 71.4 & 84.5 & 86.4 & 88.6 & 75.6 \\
\hline
\end{tabular}

Notes: We compute the sum (by year) of exports and offshoring for the firms observed in our sample (in millions of Euros). 'Offshoring' is defined as the value of imports of goods belonging to the same industry as that of the importing firm (see Section 2 for details). The average hourly wage is calculated as the average hourly wage by job category and by year for the firms of our sample. The coverage of wage agreements is calculated as the number of firms covered by a wage agreement in a given year, divided by the total number of firms. 
Dependent variable

Exports

Offshoring

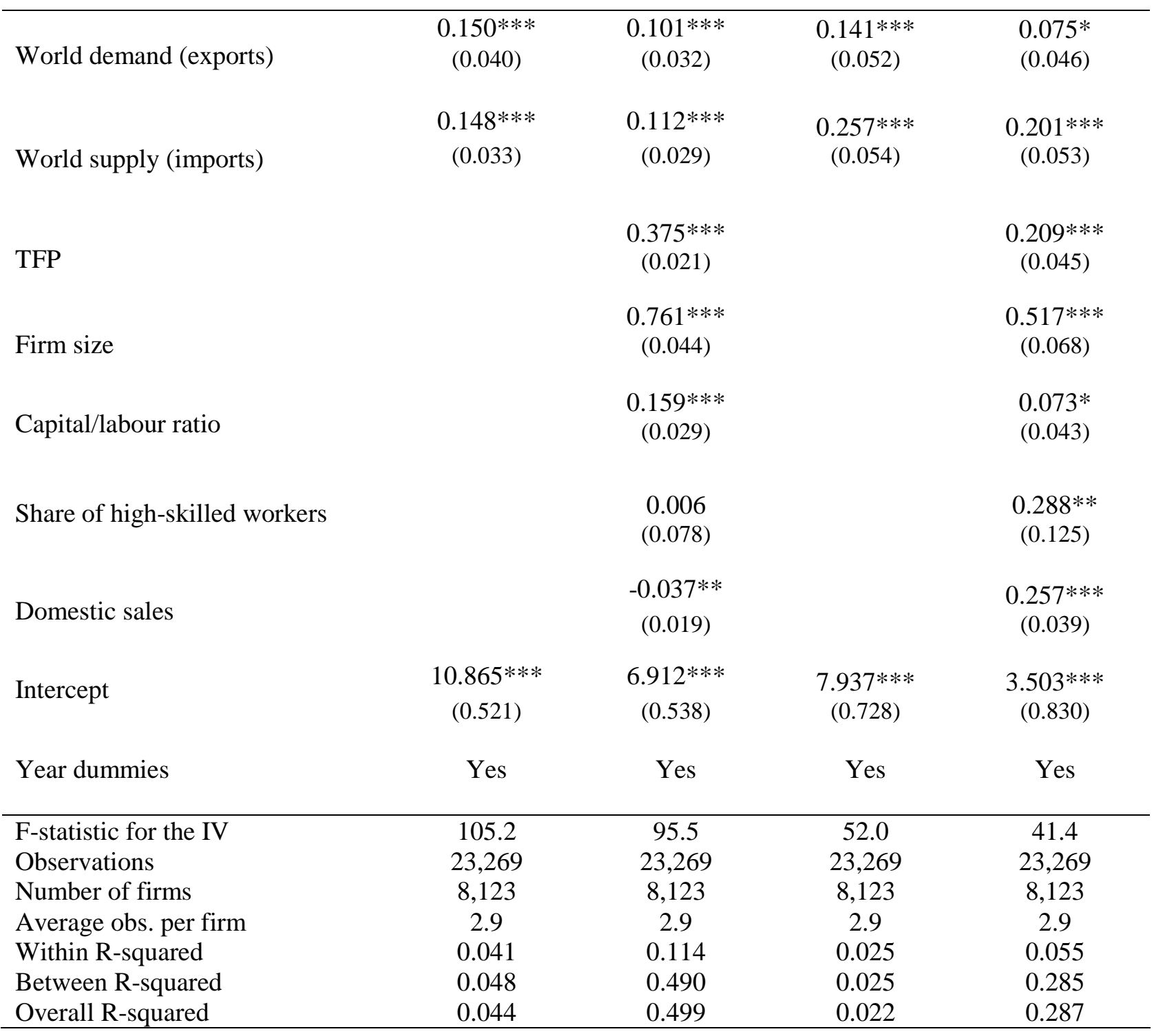

Notes: $* * * \mathrm{p}<0.01, * * \mathrm{p}<0.05, * \mathrm{p}<0.1$. Period: 2005-2009. Robust standard errors are clustered at the firm level and reported in brackets. Year dummies and firm fixed-effects are included in all specifications. 'Exports' is the log of the value of exports. 'Offshoring' is the log of the value of imports of goods belonging to the same industry as that of the importing firm (see Section 2 for details). Firm-level controls (size, TFP, capital/labour and domestic sales) are in logs. Product shares entering world demand and world supply are calculated at their overall sample (1996-2004) firm value. 
Dependent variable

Net hourly wage

(1)

(2)

(3)

(4)

\begin{tabular}{|c|c|c|c|c|}
\hline Exports & $\begin{array}{c}0.014 * * * \\
(0.001)\end{array}$ & $\begin{array}{c}0.022 * * * \\
(0.001)\end{array}$ & $\begin{array}{c}0.007 * * * \\
(0.001)\end{array}$ & $\begin{array}{c}0.010^{* * * *} \\
(0.001)\end{array}$ \\
\hline Offshoring & $\begin{array}{c}0.006^{* * * *} \\
(0.001)\end{array}$ & $\begin{array}{c}0.012 * * * \\
(0.001)\end{array}$ & $\begin{array}{c}0.003 * * * \\
(0.001)\end{array}$ & $\begin{array}{c}0.004 * * * \\
(0.001)\end{array}$ \\
\hline TFP & & & $\begin{array}{c}0.024 * * * \\
(0.003)\end{array}$ & $\begin{array}{c}0.023 * * * \\
(0.003)\end{array}$ \\
\hline Firm size & & & $\begin{array}{l}-0.002 \\
(0.003)\end{array}$ & $\begin{array}{c}-0.008 * * * \\
(0.003)\end{array}$ \\
\hline Capital/labour & & & $\begin{array}{c}0.013 * * * \\
(0.003)\end{array}$ & $\begin{array}{c}0.013 * * * \\
(0.003)\end{array}$ \\
\hline $\begin{array}{l}\text { Share of high-skilled } \\
\text { workers }\end{array}$ & & & $\begin{array}{c}0.380 * * * \\
(0.011)\end{array}$ & $\begin{array}{c}0.377 * * * \\
(0.011)\end{array}$ \\
\hline Unemployment rate & & & $\begin{array}{l}-0.000 \\
(0.001)\end{array}$ & $\begin{array}{l}-0.000 \\
(0.001)\end{array}$ \\
\hline Temporary contracts & & & $\begin{array}{c}-0.034 * * * \\
(0.010)\end{array}$ & $\begin{array}{c}-0.035^{* * *} \\
(0.010)\end{array}$ \\
\hline Domestic sales & & & $\begin{array}{l}0.003 * \\
(0.002)\end{array}$ & $\begin{array}{l}0.003 \\
(0.002)\end{array}$ \\
\hline Intercept & $\begin{array}{l}2.519 * * * \\
(0.024)\end{array}$ & $\begin{array}{c}2.347 * * * \\
(0.023)\end{array}$ & $\begin{array}{c}1.859 * * * \\
(0.023)\end{array}$ & $\begin{array}{c}1.835^{* * *} \\
(0.024)\end{array}$ \\
\hline Controls & No & No & Yes & Yes \\
\hline IV & No & Yes & No & Yes \\
\hline Observations & 23,269 & 23,269 & 23,269 & 23,269 \\
\hline Number of firms & 8,123 & 8,123 & 8,123 & 8,123 \\
\hline R-squared & 0.351 & 0.365 & 0.632 & 0.632 \\
\hline
\end{tabular}

Notes: $* * * p<0.01, * * p<0.05, * p<0.1$; Period: 2005-2009. Robust standard errors are clustered at the firm level and reported in brackets. Year and disaggregate industry-level dummies, random firm-level effects are included in all specifications. 'Net hourly wage' is the log of the average hourly wage in the firm. 'Exports' is the log of the value of exports. 'Offshoring' is the log of the value of imports of goods belonging to the same industry as that of the importing firm (see Section 2 for details). Firm-level controls (size, TFP, capital/labour and domestic sales) are in logs. 
Table 5: Firm-level Wage Regressions (by Occupation)

\begin{tabular}{|c|c|c|c|c|c|c|c|c|}
\hline \multirow[t]{3}{*}{$\begin{array}{l}\text { Dependent } \\
\text { variable }\end{array}$} & \multicolumn{8}{|c|}{ Net hourly wage } \\
\hline & \multicolumn{2}{|c|}{ Blue collar } & \multicolumn{2}{|c|}{ White-collar } & \multicolumn{2}{|c|}{ Technicians } & \multicolumn{2}{|c|}{ Executives } \\
\hline & OLS & OLS-IV & OLS & OLS-IV & OLS & OLS-IV & OLS & OLS-IV \\
\hline Exports & $\begin{array}{c}0.004 * * * \\
(0.001)\end{array}$ & $\begin{array}{c}0.004 * * * \\
(0.001)\end{array}$ & $\begin{array}{c}0.005^{* * *} * \\
(0.001)\end{array}$ & $\begin{array}{c}0.007 * * * \\
(0.001)\end{array}$ & $\begin{array}{c}0.003^{* *} \\
(0.001)\end{array}$ & $\begin{array}{l}0.002 * \\
(0.001)\end{array}$ & $\begin{array}{c}0.004 * * * \\
(0.002)\end{array}$ & $\begin{array}{c}0.003 * * \\
(0.002)\end{array}$ \\
\hline Offshoring & $\begin{array}{c}0.000 \\
(0.001)\end{array}$ & $\begin{array}{l}-0.001 \\
(0.001)\end{array}$ & $\begin{array}{l}0.000 \\
(0.001)\end{array}$ & $\begin{array}{c}0.000 \\
(0.001)\end{array}$ & $\begin{array}{c}0.003 * * * \\
(0.001)\end{array}$ & $\begin{array}{c}0.004^{* * * *} \\
(0.001)\end{array}$ & $\begin{array}{c}0.004 * * * \\
(0.001)\end{array}$ & $\begin{array}{c}0.007 * * * \\
(0.001)\end{array}$ \\
\hline TFP & $\begin{array}{c}0.021 * * * \\
(0.004)\end{array}$ & $\begin{array}{c}0.021 * * * \\
(0.004)\end{array}$ & $\begin{array}{c}0.012 * * * \\
(0.004)\end{array}$ & $\begin{array}{c}0.011 * * \\
(0.004)\end{array}$ & $\begin{array}{c}0.029 * * * \\
(0.004)\end{array}$ & $\begin{array}{c}0.029 * * * \\
(0.004)\end{array}$ & $\begin{array}{c}0.032 * * * \\
(0.005)\end{array}$ & $\begin{array}{c}0.032 * * * \\
(0.005)\end{array}$ \\
\hline Firm size & $\begin{array}{c}0.019 * * * \\
(0.003)\end{array}$ & $\begin{array}{c}0.020 * * * \\
(0.003)\end{array}$ & $\begin{array}{c}0.021 * * * \\
(0.003)\end{array}$ & $\begin{array}{c}0.018 * * * \\
(0.003)\end{array}$ & $\begin{array}{c}-0.008 * * \\
(0.003)\end{array}$ & $\begin{array}{c}-0.008 * * \\
(0.003)\end{array}$ & $\begin{array}{c}0.013 * * * \\
(0.004)\end{array}$ & $\begin{array}{c}0.012 * * * \\
(0.004)\end{array}$ \\
\hline Capital/labour & $\begin{array}{c}0.009 * * \\
(0.004)\end{array}$ & $\begin{array}{c}0.009 * * \\
(0.004)\end{array}$ & $\begin{array}{c}0.016 * * * \\
(0.005)\end{array}$ & $\begin{array}{c}0.016^{* * * *} \\
(0.005)\end{array}$ & $\begin{array}{c}0.012 * * \\
(0.005)\end{array}$ & $\begin{array}{c}0.012 * * \\
(0.005)\end{array}$ & $\begin{array}{l}-0.002 \\
(0.007)\end{array}$ & $\begin{array}{l}-0.002 \\
(0.007)\end{array}$ \\
\hline $\begin{array}{l}\text { Share of high- } \\
\text { skilled workers }\end{array}$ & $\begin{array}{c}0.028^{* * *} \\
(0.009)\end{array}$ & $\begin{array}{c}0.029 * * * \\
(0.009)\end{array}$ & $\begin{array}{l}-0.006 \\
(0.010)\end{array}$ & $\begin{array}{l}-0.008 \\
(0.010)\end{array}$ & $\begin{array}{c}-0.119 * * * \\
(0.012)\end{array}$ & $\begin{array}{c}-0.120 * * * \\
(0.012)\end{array}$ & $\begin{array}{c}-0.052 * * * \\
(0.014)\end{array}$ & $\begin{array}{c}-0.055^{* * * *} \\
(0.014)\end{array}$ \\
\hline Unemp. rate & $\begin{array}{c}-0.002 * * * \\
(0.001)\end{array}$ & $\begin{array}{c}-0.002 * * * \\
(0.001)\end{array}$ & $\begin{array}{l}-0.000 \\
(0.001)\end{array}$ & $\begin{array}{l}-0.000 \\
(0.001)\end{array}$ & $\begin{array}{l}-0.001 \\
(0.001)\end{array}$ & $\begin{array}{l}-0.001 \\
(0.001)\end{array}$ & $\begin{array}{c}0.001 \\
(0.001)\end{array}$ & $\begin{array}{c}0.001 \\
(0.001)\end{array}$ \\
\hline $\begin{array}{l}\text { Temporary } \\
\text { contracts }\end{array}$ & $\begin{array}{c}-0.049 * * * \\
(0.011)\end{array}$ & $\begin{array}{c}-0.049 * * * \\
(0.011)\end{array}$ & $\begin{array}{c}-0.071 * * * \\
(0.014)\end{array}$ & $\begin{array}{c}-0.072 * * * \\
(0.014)\end{array}$ & $\begin{array}{c}-0.077 * * * \\
(0.015)\end{array}$ & $\begin{array}{c}-0.078 * * * \\
(0.015)\end{array}$ & $\begin{array}{c}-0.035^{*} \\
(0.020)\end{array}$ & $\begin{array}{c}-0.037^{*} \\
(0.020)\end{array}$ \\
\hline Domestic sales & $\begin{array}{l}0.004 * \\
(0.002)\end{array}$ & $\begin{array}{l}0.004 * \\
(0.002)\end{array}$ & $\begin{array}{c}0.002 \\
(0.004)\end{array}$ & $\begin{array}{c}0.002 \\
(0.004)\end{array}$ & $\begin{array}{c}0.003 \\
(0.003)\end{array}$ & $\begin{array}{c}0.003 \\
(0.003)\end{array}$ & $\begin{array}{c}0.009 * * \\
(0.004)\end{array}$ & $\begin{array}{l}0.007 * \\
(0.004)\end{array}$ \\
\hline Intercept & $\begin{array}{c}1.989 * * * \\
(0.024)\end{array}$ & $\begin{array}{c}1.991 * * * \\
(0.024)\end{array}$ & $\begin{array}{c}2.144 * * * \\
(0.025)\end{array}$ & $\begin{array}{c}2.135 * * * \\
(0.026)\end{array}$ & $\begin{array}{c}2.364 * * * \\
(0.032)\end{array}$ & $\begin{array}{c}2.360 * * * \\
(0.032)\end{array}$ & $\begin{array}{c}2.683 * * * \\
(0.039)\end{array}$ & $\begin{array}{c}2.675 * * * \\
(0.039)\end{array}$ \\
\hline IV & No & Yes & No & Yes & No & Yes & No & Yes \\
\hline Observations & 23,269 & 23,269 & 23,269 & 23,269 & 23,269 & 23,269 & 23,269 & 23,269 \\
\hline $\mathrm{Nr}$ of firms & 8,123 & 8,123 & 8,123 & 8,123 & 8,123 & 8,123 & 8,123 & 8,123 \\
\hline R-squared & 0.416 & 0.416 & 0.258 & 0.258 & 0.186 & 0.186 & 0.186 & 0.187 \\
\hline
\end{tabular}

Notes: *** $\mathrm{p}<0.01, * * \mathrm{p}<0.05$, $\mathrm{p}<0.1$; Period: 2005-2009. Robust standard errors are clustered at the firm level and reported in brackets. Year and disaggregate industry-level dummies, random firm-level effects are included in all specifications. 'Net hourly wage' is the log of the average hourly wage by job occupation in the firm. 'Exports' is the log of the value of exports. 'Offshoring' is the log of the value of imports of goods belonging to the same industry as that of the importing firm (see Section 2 for details). Firm-level controls (size, TFP, capital/labour and domestic sales) are in logs. 
Table 6: Firm-level Wage Regressions by Wage Bargaining Regime (All Workers)

\begin{tabular}{|c|c|c|c|c|c|c|}
\hline \multirow{3}{*}{$\begin{array}{l}\text { Dependent variable } \\
\text { Firm wage agreement }\end{array}$} & \multicolumn{6}{|c|}{ Net hourly wage } \\
\hline & \multicolumn{3}{|c|}{ 2005-2009 } & \multicolumn{3}{|c|}{$2005-2008$} \\
\hline & No & No & Yes & No & No & Yes \\
\hline Industry wage agreement & No & Yes & - & No & Yes & - \\
\hline Exports & $\begin{array}{c}0.010 * * * \\
(0.002)\end{array}$ & $\begin{array}{c}0.010 * * * \\
(0.001)\end{array}$ & $\begin{array}{c}0.015 * * * \\
(0.003)\end{array}$ & $\begin{array}{c}0.011 * * * \\
(0.002)\end{array}$ & $\begin{array}{c}0.010 * * * \\
(0.001)\end{array}$ & $\begin{array}{c}0.015 * * * \\
(0.003)\end{array}$ \\
\hline Offshoring & $\begin{array}{l}-0.001 \\
(0.002)\end{array}$ & $\begin{array}{c}0.004 * * * \\
(0.001)\end{array}$ & $\begin{array}{c}0.002 \\
(0.002)\end{array}$ & $\begin{array}{c}-0.004 * \\
(0.002)\end{array}$ & $\begin{array}{c}0.003^{* * *} \\
(0.001)\end{array}$ & $\begin{array}{l}0.003 * \\
(0.002)\end{array}$ \\
\hline TFP & $\begin{array}{c}0.021 * * \\
(0.010)\end{array}$ & $\begin{array}{c}0.021 * * * \\
(0.004)\end{array}$ & $\begin{array}{c}0.024 * * * \\
(0.005)\end{array}$ & $\begin{array}{c}0.023 * * \\
(0.011)\end{array}$ & $\begin{array}{c}0.016^{* * * *} \\
(0.004)\end{array}$ & $\begin{array}{c}0.017 * * * \\
(0.005)\end{array}$ \\
\hline Firm size & $\begin{array}{c}-0.014 * * \\
(0.006)\end{array}$ & $\begin{array}{c}-0.010 * * * \\
(0.004)\end{array}$ & $\begin{array}{l}-0.007 \\
(0.007)\end{array}$ & $\begin{array}{c}-0.016^{* *} \\
(0.008)\end{array}$ & $\begin{array}{c}-0.012 * * * \\
(0.004)\end{array}$ & $\begin{array}{l}-0.009 \\
(0.007)\end{array}$ \\
\hline Capital/labour & $\begin{array}{c}0.022 * * \\
(0.011)\end{array}$ & $\begin{array}{c}0.012 * * * \\
(0.005)\end{array}$ & $\begin{array}{c}0.009 \\
(0.008)\end{array}$ & $\begin{array}{l}0.022 * \\
(0.013)\end{array}$ & $\begin{array}{c}0.014 * * * \\
(0.005)\end{array}$ & $\begin{array}{c}0.009 \\
(0.008)\end{array}$ \\
\hline $\begin{array}{l}\text { Share of high-skilled } \\
\text { workers }\end{array}$ & $\begin{array}{c}0.498 * * * \\
(0.021)\end{array}$ & $\begin{array}{c}0.381 * * * \\
(0.013)\end{array}$ & $\begin{array}{c}0.413 * * * \\
(0.038)\end{array}$ & $\begin{array}{c}0.503 * * * \\
(0.024)\end{array}$ & $\begin{array}{c}0.425 * * * \\
(0.016)\end{array}$ & $\begin{array}{c}0.462 * * * \\
(0.059)\end{array}$ \\
\hline Unemployment rate & $\begin{array}{c}0.001 \\
(0.001)\end{array}$ & $\begin{array}{l}-0.000 \\
(0.001)\end{array}$ & $\begin{array}{l}-0.000 \\
(0.001)\end{array}$ & $\begin{array}{c}0.002 \\
(0.002)\end{array}$ & $\begin{array}{c}0.001 \\
(0.001)\end{array}$ & $\begin{array}{c}0.001 \\
(0.002)\end{array}$ \\
\hline Temporary contracts & $\begin{array}{l}-0.041 \\
(0.029)\end{array}$ & $\begin{array}{c}-0.046 * * * \\
(0.012)\end{array}$ & $\begin{array}{l}-0.041 \\
(0.029)\end{array}$ & $\begin{array}{l}-0.028 \\
(0.031)\end{array}$ & $\begin{array}{c}-0.052 * * * \\
(0.013)\end{array}$ & $\begin{array}{c}-0.058 * * \\
(0.025)\end{array}$ \\
\hline Domestic sales & $\begin{array}{c}0.026 * * \\
(0.012)\end{array}$ & $\begin{array}{c}0.004 \\
(0.003)\end{array}$ & $\begin{array}{l}-0.004 \\
(0.004)\end{array}$ & $\begin{array}{c}0.027 * * * \\
(0.010)\end{array}$ & $\begin{array}{l}0.005^{*} \\
(0.003)\end{array}$ & $\begin{array}{l}-0.003 \\
(0.003)\end{array}$ \\
\hline Intercept & $\begin{array}{c}1.841 * * * \\
(0.044)\end{array}$ & $\begin{array}{c}1.865^{* * * *} \\
(0.030)\end{array}$ & $\begin{array}{c}1.810 * * * \\
(0.065)\end{array}$ & $\begin{array}{c}1.808 * * * \\
(0.048)\end{array}$ & $\begin{array}{c}1.835^{* * *} \\
(0.032)\end{array}$ & $\begin{array}{c}1.760 * * * \\
(0.064)\end{array}$ \\
\hline Controls & Yes & Yes & Yes & Yes & Yes & Yes \\
\hline IV & Yes & Yes & Yes & Yes & Yes & Yes \\
\hline Observations & 3,509 & 14,683 & 5,077 & 2,726 & 12,181 & 4,138 \\
\hline Number of firms & 2,556 & 6,124 & 1,293 & 1,964 & 5,586 & 1,260 \\
\hline R-Squared & 0.625 & 0.604 & 0.736 & 0.622 & 0.617 & 0.749 \\
\hline
\end{tabular}

Notes: *** $\mathrm{p}<0.01, * * \mathrm{p}<0.05, * \mathrm{p}<0.1$; Period: 2005-2009 and 2005-2008. Robust standard errors are clustered at the firm level and reported in brackets. Year and disaggregate industry-level dummies, random firm-level effects are included in all specifications. 'Net hourly wage' is the log of the average hourly wage in the firm. 'Exports' is the $\log$ of the value of exports. 'Offshoring' is the log of the value of imports of goods belonging to the same industry as that of the importing firm (see Section 2 for details). Firm-level controls (size, TFP, capital/labour and domestic sales) are in logs. The category 'Firm-level wage agreement' is defined according to the frequency of firm-level wage agreements for a given firm, 'Yes' corresponds to firms that agree on wages more than $20 \%$ of years over the period 2002-2009, 'No' less than $20 \%$ of wage agreements over the same period. The category 'Industry-level wage agreement' means that a firm is covered by an industry-wage agreement in a given year. 
Table 7: Firm-level Wage Regressions by Bargaining Regime and by Occupation

\begin{tabular}{|c|c|c|c|c|c|c|}
\hline \multirow{3}{*}{$\begin{array}{l}\text { Dependent variable } \\
\text { Firm wage agreement }\end{array}$} & \multicolumn{6}{|c|}{ Net hourly wage } \\
\hline & \multicolumn{3}{|c|}{ 2005-2009 } & \multicolumn{3}{|c|}{$2005-2008$} \\
\hline & No & No & Yes & No & No & Yes \\
\hline Industry wage agreement & No & Yes & - & No & Yes & - \\
\hline \multicolumn{7}{|l|}{ Blue-collar workers } \\
\hline Exports & $\begin{array}{l}0.004 * \\
(0.002)\end{array}$ & $\begin{array}{c}0.003 * * * \\
(0.001)\end{array}$ & $\begin{array}{c}0.011 * * * \\
(0.003)\end{array}$ & $\begin{array}{c}0.005 * * \\
(0.002)\end{array}$ & $\begin{array}{c}0.003 * * \\
(0.001)\end{array}$ & $\begin{array}{c}0.011 * * * \\
(0.003)\end{array}$ \\
\hline Offshoring & $\begin{array}{l}-0.003 \\
(0.002)\end{array}$ & $\begin{array}{l}-0.001 \\
(0.001)\end{array}$ & $\begin{array}{l}-0.001 \\
(0.002)\end{array}$ & $\begin{array}{c}-0.005^{* *} \\
(0.002)\end{array}$ & $\begin{array}{c}-0.002 * * \\
(0.001)\end{array}$ & $\begin{array}{c}0.000 \\
(0.002)\end{array}$ \\
\hline R-Squared & 0.424 & 0.346 & 0.538 & 0.407 & 0.343 & 0.539 \\
\hline \multicolumn{7}{|l|}{ White-collar workers } \\
\hline Exports & $\begin{array}{c}0.006^{* *} \\
(0.003)\end{array}$ & $\begin{array}{c}0.007 * * * \\
(0.001)\end{array}$ & $\begin{array}{l}0.006^{*} \\
(0.003)\end{array}$ & $\begin{array}{c}0.009 * * * \\
(0.003)\end{array}$ & $\begin{array}{c}0.006 * * * \\
(0.002)\end{array}$ & $\begin{array}{c}0.008 * * \\
(0.004)\end{array}$ \\
\hline Offshoring & $\begin{array}{c}-0.004 * \\
(0.002)\end{array}$ & $\begin{array}{l}-0.000 \\
(0.001)\end{array}$ & $\begin{array}{c}0.003 \\
(0.002)\end{array}$ & $\begin{array}{c}-0.007 * * * \\
(0.002)\end{array}$ & $\begin{array}{l}-0.000 \\
(0.001)\end{array}$ & $\begin{array}{l}0.004^{*} \\
(0.002)\end{array}$ \\
\hline R-Squared & 0.276 & 0.202 & 0.364 & 0.248 & 0.189 & 0.374 \\
\hline \multicolumn{7}{|l|}{ Technicians and supervisors } \\
\hline Exports & $\begin{array}{l}0.005^{*} \\
(0.003)\end{array}$ & $\begin{array}{c}0.002 \\
(0.002)\end{array}$ & $\begin{array}{c}0.007 * * \\
(0.003)\end{array}$ & $\begin{array}{c}0.002 \\
(0.003)\end{array}$ & $\begin{array}{c}0.001 \\
(0.002)\end{array}$ & $\begin{array}{c}0.007 * * \\
(0.003)\end{array}$ \\
\hline Offshoring & $\begin{array}{c}0.000 \\
(0.002)\end{array}$ & $\begin{array}{c}0.004 * * * \\
(0.001)\end{array}$ & $\begin{array}{c}0.003 \\
(0.002)\end{array}$ & $\begin{array}{c}0.000 \\
(0.003)\end{array}$ & $\begin{array}{c}0.004 * * * \\
(0.001)\end{array}$ & $\begin{array}{l}0.004 * \\
(0.002)\end{array}$ \\
\hline R-Squared & 0.208 & 0.168 & 0.340 & 0.210 & 0.172 & 0.346 \\
\hline \multicolumn{7}{|l|}{ Executives } \\
\hline Exports & $\begin{array}{c}0.004 \\
(0.004)\end{array}$ & $\begin{array}{c}0.002 \\
(0.002)\end{array}$ & $\begin{array}{c}0.011 * * * \\
(0.004)\end{array}$ & $\begin{array}{c}0.005 \\
(0.004)\end{array}$ & $\begin{array}{c}0.001 \\
(0.002)\end{array}$ & $\begin{array}{c}0.011 * * * \\
(0.004)\end{array}$ \\
\hline Offshoring & $\begin{array}{c}0.002 \\
(0.003)\end{array}$ & $\begin{array}{c}0.009 * * * \\
(0.002)\end{array}$ & $\begin{array}{c}0.006^{* *} \\
(0.003)\end{array}$ & $\begin{array}{l}-0.001 \\
(0.004)\end{array}$ & $\begin{array}{c}0.009 * * * \\
(0.002)\end{array}$ & $\begin{array}{c}0.007 * * \\
(0.003)\end{array}$ \\
\hline R-Squared & 0.192 & 0.161 & 0.317 & 0.195 & 0.167 & 0.330 \\
\hline Observations & 3,509 & 14,683 & 5,077 & 2,726 & 12,181 & 4,138 \\
\hline Number of firms & 2,556 & 6,124 & 1,293 & 1,964 & 5,586 & 1,260 \\
\hline
\end{tabular}

Notes: $* * * \mathrm{p}<0.01, * * \mathrm{p}<0.05, * \mathrm{p}<0.1$; Period: 2005-2009 and 2005-2008. Robust standard errors are clustered at the firm level and reported in brackets. Year and disaggregate industry-level dummies, random firm-level effects and firm-level control variables $(\mathrm{TFP}, . .$.$) are included in all specifications. 'Net hourly wage' is the log of the average$ hourly wage in the firm. 'Exports' is the log of the value of exports. 'Offshoring' is the log of the value of imports of goods belonging to the same industry as that of the importing firm (see Section 2 for details). The category 'Firmlevel wage agreement' is defined according to the frequency of firm-level wage agreements for a given firm, 'Yes' corresponds to firms that agree on wages more than $20 \%$ of years over the period 2002-2009, 'No' less than $20 \%$ of wage agreements over the same period. The category 'Industry-level wage agreement' means that a firm is covered by an industry-wage agreement in a given year. 


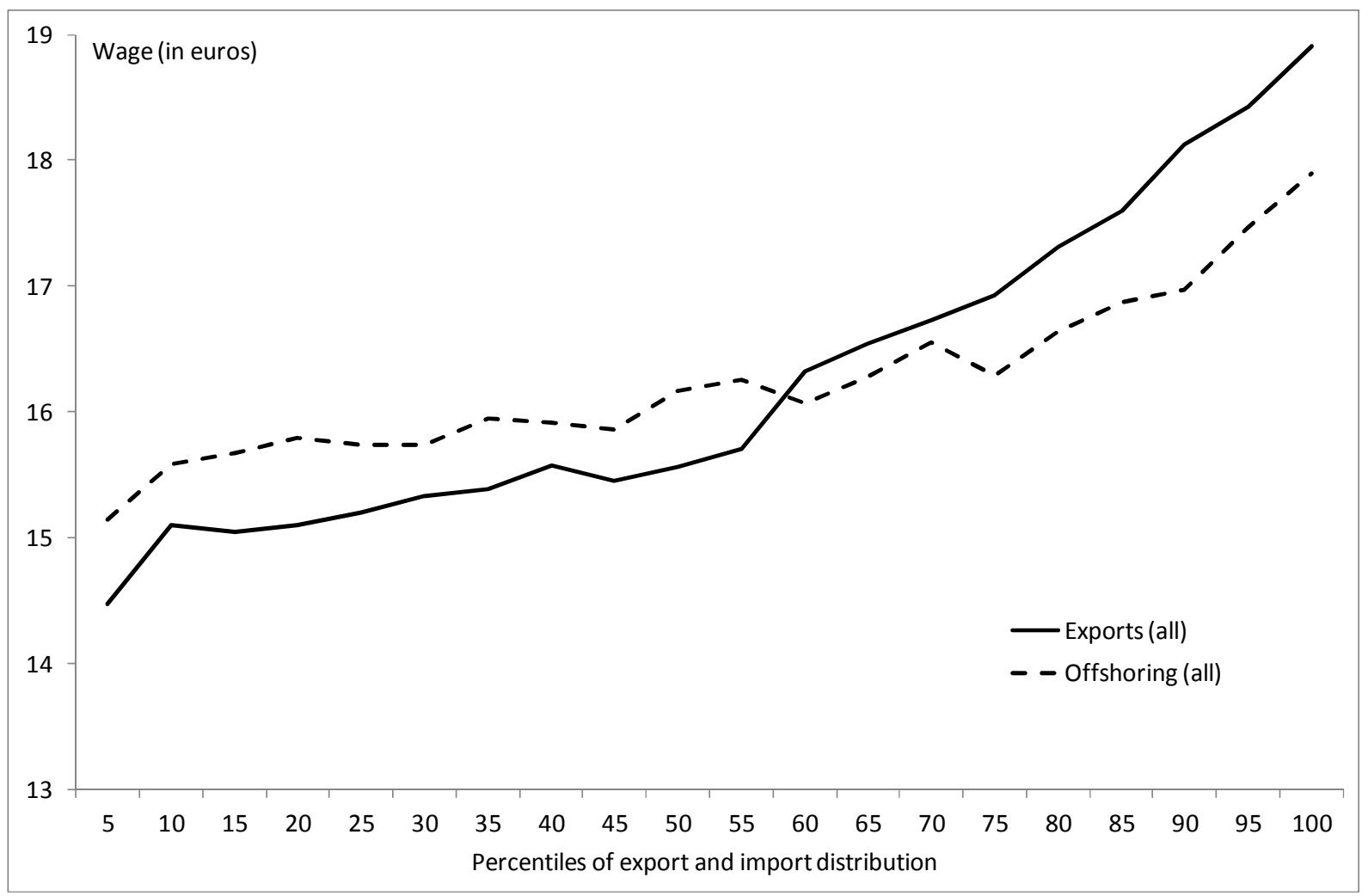

Notes: We report the average hourly wage in euros as a function of percentiles of the export and offshoring distribution. 'Offshoring' is defined as imports of goods belonging to the same industry as that of the importing firm (see Section 2 for details). We use export and offshoring per employee to control for wage differences due to firm size differences. We then compute percentiles of the sample distribution and calculate the average hourly wage at each percentile of the export and import distributions. Period: 2005-2009. 
Figure 2: Average Wages by Percentiles of the Export and Offshoring Distributions by Occupation
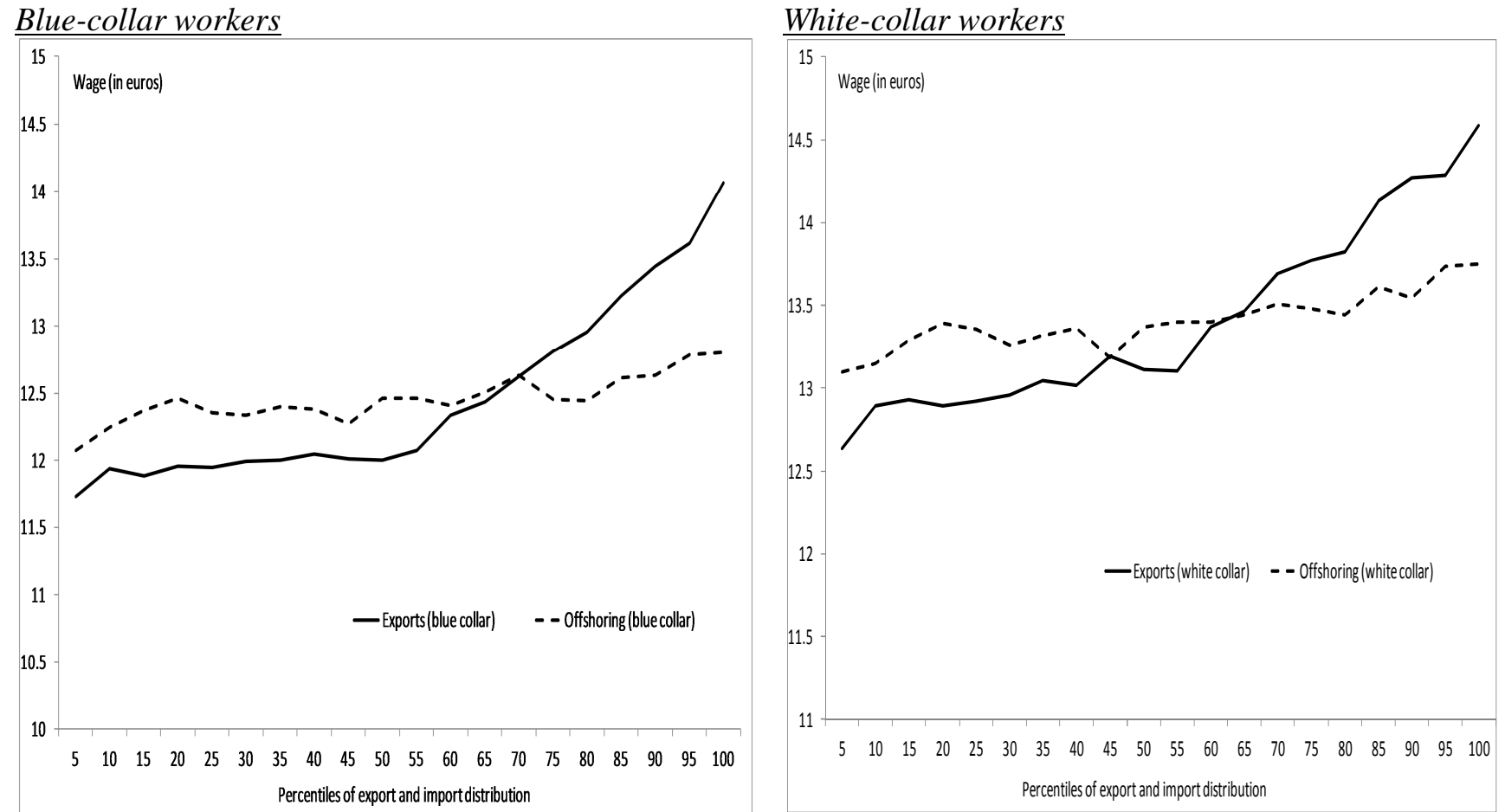

\section{$\underline{\text { Technicians and supervisors }}$}
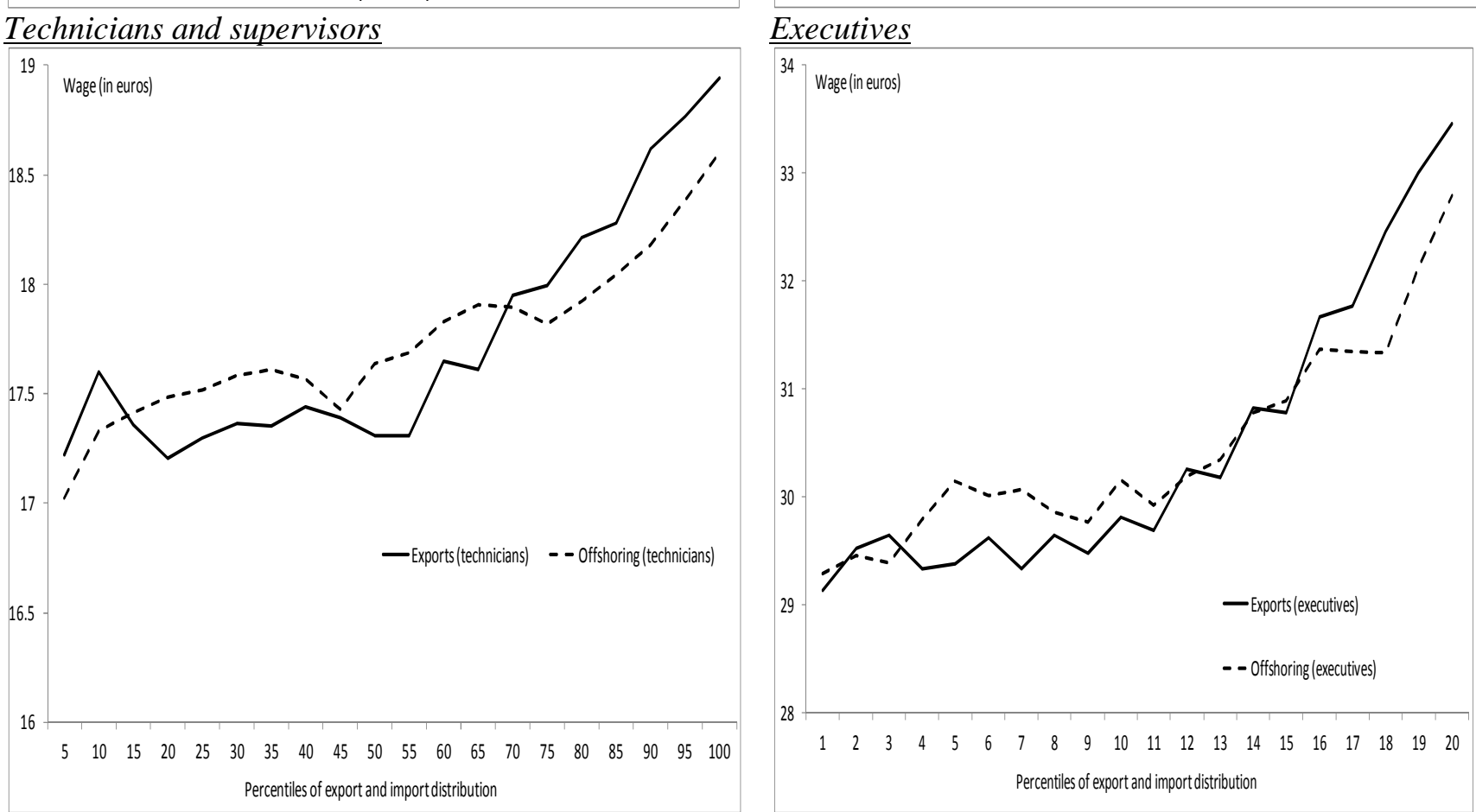

Notes: We report the average hourly wage in euros as a function of percentiles of the export and offshoring distribution. 'Offshoring' is defined as imports of goods belonging to the same industry as that of the importing firm (see Section 2 for details). We use export and offshoring per employee to control for wage differences due to firm size differences. We then compute percentiles of the sample distribution and calculate the average hourly wage at each percentile of the export and import distributions. Period: 2005-2009. 


\section{APPENDIX A. Breakdown of Wage Agreements}

Table A1: Firm-level Agreements by Topic

\begin{tabular}{lc}
\hline Topic & Percentage \\
\hline Wages & 70.03 \\
Union rights & 8.51 \\
Sex discrimination & 4.81 \\
Employment & 3.42 \\
On-the-job training & 2.40 \\
Human resources management & 2.09 \\
Disabled workers & 2.04 \\
Labour conditions & 1.97 \\
Job classifications & 1.76 \\
Other topics & 2.96 \\
\hline
\end{tabular}

Notes: Statistics are calculated using the data set of all firm level agreements on the period 2005-2009. Percentages are calculated as the share of each topic in all agreements. 


\section{Appendix B. Estimating Sample}

Table B1: Firm-level Average Hourly Wage Regressions (Total) - Different Samples

Dependent variable: hourly average wage

\section{All observations $\quad$ Excluding observations below}

Excl. $5^{\text {th }}$ percentile Excl. $10^{\text {th }}$ percentile Excl. $20^{\text {th }}$ percentile

(1)

\section{OLS}

(2)
(3)
(4)

\begin{tabular}{lcccccccc} 
& OLS & OLS-IV & OLS & OLS-IV & OLS & OLS-IV & OLS & OLS-IV \\
\hline \multirow{2}{*}{ Exports } & & & & & & & & \\
& $0.005^{* * *}$ & $0.008^{* * *}$ & $0.007 * * *$ & $0.010^{* * *}$ & $0.008^{* * *}$ & $0.012^{* * *}$ & $0.011^{* * * *}$ & $0.018^{* * *}$ \\
Offshoring & $(0.001)$ & $(0.001)$ & $(0.001)$ & $(0.001)$ & $(0.001)$ & $(0.001)$ & $(0.001)$ & $(0.002)$ \\
& $0.002^{* * *}$ & $0.004^{* * *}$ & $0.003^{* * *}$ & $0.004^{* * *}$ & $0.002 * * *$ & $0.004 * * *$ & $0.003^{* * *}$ & $0.004 * * *$ \\
& $(0.000)$ & $(0.001)$ & $(0.001)$ & $(0.001)$ & $(0.001)$ & $(0.001)$ & $(0.001)$ & $(0.001)$ \\
Controls & & & & & & & & \\
Observations & Yes & Yes & Yes & Yes & Yes & Yes & Yes & Yes \\
Number of firms & 25,742 & 25,742 & 23,269 & 23,269 & 21,055 & 21,055 & 17,289 & 17,289 \\
R-squared & 8,824 & 8,824 & 8,123 & 8,123 & 7,364 & 7,364 & 6,054 & 6,054 \\
\hline
\end{tabular}

Notes: $* * * \mathrm{p}<0.01, * * \mathrm{p}<0.05, * \mathrm{p}<0.1$; Period: 2005-2009. Robust standard errors are clustered at the firm level and reported in brackets. Year and disaggregate industry-level dummies, random firm-level effects and firm-level control variables $(\mathrm{TFP}, \ldots)$ are included in all specifications. 'Net hourly wage' is the log of the average hourly wage in the firm. 'Exports' is the log of the value of exports. 'Offshoring' is the log of the value of imports of goods belonging to the same industry as that of the importing firm (see Section 2 for details). The four samples considered are constructed according to a different sample selection criterion. For every firm*year we compute the ratio of exports to total sales ('export intensity') and the ratio of offshoring to total sales ('offshoring intensity'). We then build four different samples: (1) we keep all observations (firm*year) with positive exports and imports; (2) we exclude observations below the $5^{\text {th }}$ percentiles of both distributions of ratios; (3) we exclude observations below the $10^{\text {th }}$ percentiles and (4) we exclude observations below the $20^{\text {th }}$ percentiles. 


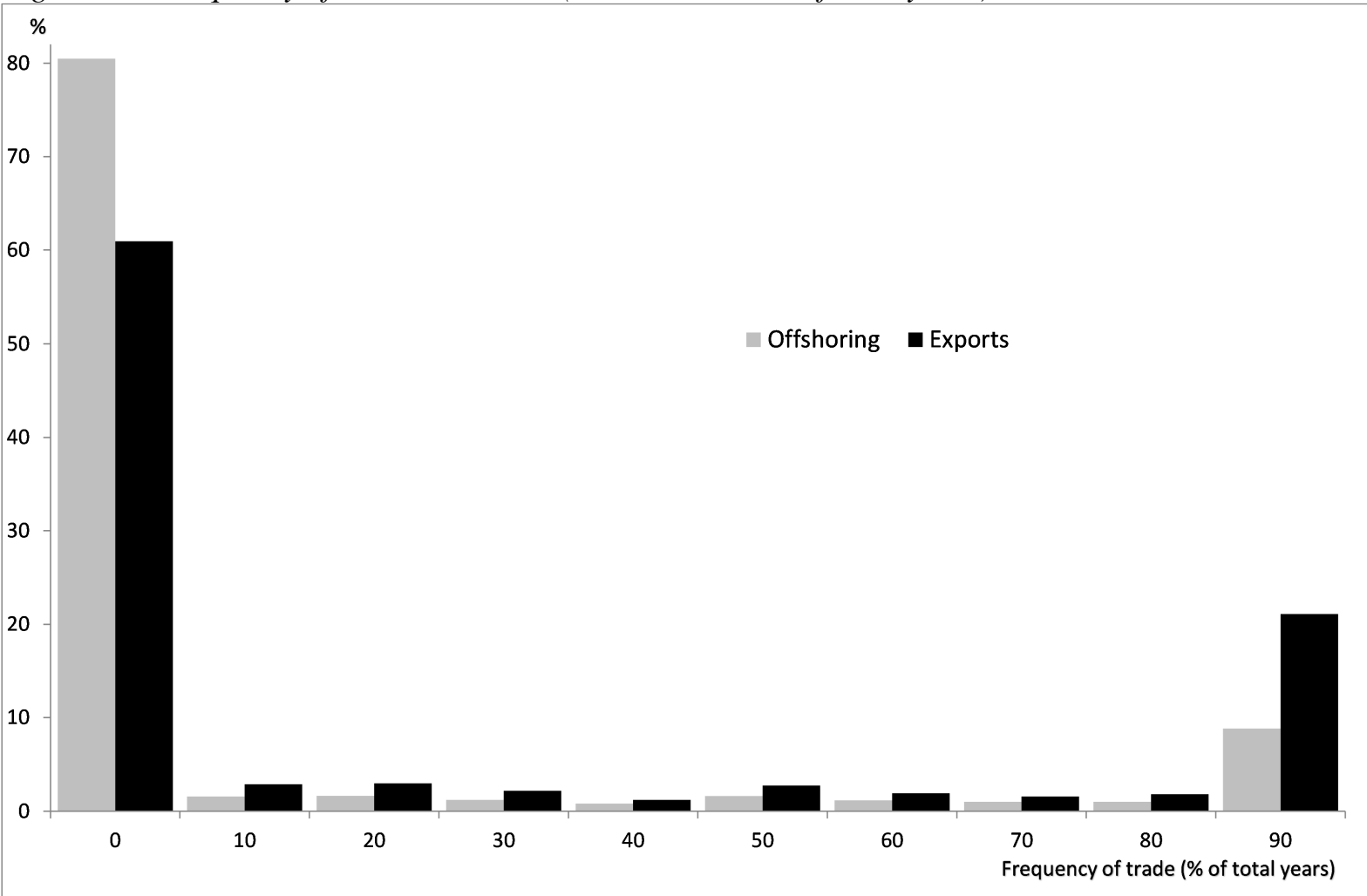

Notes: Each observation is a firm. The sample consists of all firms observed over the period 1996-2009 and for which we have balance-sheet information (BRN data set). We compute the 'frequency of exports' as the number of years a given firm reports positive exports divided by the total number of years this firm is observed in our data set. Similar calculations are made for offshoring. 'Offshoring' is defined as imports of goods belonging to the same industry as that of the importing firm (see Section 2 for details). The figure reports the distribution of those frequencies in our data. For instance, a little more than $60 \%$ of firms never export over our sample period. 
Table B3: Variance Decomposition of Exports, Offshoring and Wages

\begin{tabular}{lcccccc}
\hline $\begin{array}{l}\text { Variance } \\
\text { log... }\end{array}$ & \multicolumn{2}{c}{$1996-2009$} & \multicolumn{2}{c}{$2005-2009$} & $2002-2009$ & $\begin{array}{c}2005-2009 \\
\text { Average }\end{array}$ \\
\hline Total & Exports & Offshoring & Exports & Offshoring & $\begin{array}{c}\text { Average } \\
\text { hourly wage }\end{array}$ \\
Between & 5.41 & 6.27 & 4.64 & 5.38 & 0.05 & 0.04 \\
Within & 4.80 & 4.84 & 4.49 & 4.98 & 0.04 & 0.04 \\
Nr obs. & 0.61 & 1.44 & 0.15 & 0.40 & 0.01 & 0.00 \\
\hline
\end{tabular}

Notes: The sample consists of the 8,123 firms in our estimating sample. For some variables, we are able to have information for a longer period 1996-2009 for trade and 2002-2009 for the average hourly wage at the firm level. 'hourly wage' is the $\log$ of the average hourly wage in the firm. 'Exports' is the log of the value of exports. 'Offshoring' is the log of the value of imports of goods belonging to the same industry as that of the importing firm (see Section 2 for details). We compute a decomposition of the variance of trade and wages for the period 20052009 (our estimating period) and for the longer period. We report the total variance of the variables, the variance due to differences between firms ('between') and the variance due to differences over time within the same firm ('within'). 


\section{Appendix C. Robustness of the Instrumentation Strategy}

Table C1: Stability Over Time of the set of Products and Countries (1996-2009)

\begin{tabular}{lcccc}
\hline & \multicolumn{2}{c}{ Exports } & \multicolumn{2}{c}{ Offshoring } \\
\hline & Mean & Median & Mean & Median \\
\hline & & & & \\
Share of trade.... & & & & \\
Top 1 product & 0.69 & 0.71 & 0.81 & 0.90 \\
Top 2 products & 0.83 & 0.89 & 0.90 & 0.98 \\
Top 1 country & 0.52 & 0.46 & 0.76 & 0.81 \\
Top 2 countries & 0.67 & 0.66 & 0.88 & 0.93 \\
Top 1 product*country pair & 0.36 & 0.43 & 0.68 & 0.68 \\
Top 2 product*country pairs & 0.57 & 0.55 & 0.80 & 0.86 \\
& & & & \\
Number of product changes .... & & & & \\
Top 1 product & 1.7 & 1 & 1.4 & 1 \\
Top 2 products & 4.1 & 4 & 2.1 & 2 \\
Top 1 country & 2.4 & 2 & 1.8 & 2 \\
Top 2 countries & 4.1 & 4 & 2.9 & 3 \\
Top 1 product*country pair & 3.8 & 3 & 2.7 & 2 \\
Top 2 product*country pairs & 6.9 & 6 & 4.7 & 4 \\
& & & & \\
\hline
\end{tabular}

Notes: The sample consists of the 8,123 firms of our estimating sample. Using customs data set on the period 19962009 , we select for each firm in a given year the main or the two main traded products. For that, we use the ratio of exports (resp. offshoring) of a product on total exports (resp. offshoring) of the firm in a given year at a very disaggregate level (HS6) over the period 1996-2009. We calculate the average share of those products among total exports (offshoring) of a given firm and how many times the major product (or top 2 products) is modified in a firm (on average over the period). We run the same analysis for countries of destination and origin and for the pairs product*country. 'Offshoring' is defined as imports of goods belonging to the same industry as that of the importing firm (see Section 2 for details). 
Table C2: Frequency of the Set of Products and Countries of Origin/Destination (1996-2004)

\section{$1^{\text {st }}$ quartile Median $3^{\text {rd }}$ quartile}

\section{Exports}

$\mathrm{Nr}$ of firms with the same main product*country pair $\mathrm{Nr}$ of firms with the same Top 2 product*country pairs

$3.8 \quad 10.8$

$1.0 \quad 1.8$

\section{Offshoring}

$\mathrm{Nr}$ of firms with the same main product*country pair

Notes: The sample consists of the 8,123 firms in our estimating sample. Using customs data set on the period 19962009, we select for every firm the main pair of country*product (using the ratio of exports/offshoring to country $c$ of product $p$ on total exports/ offshoring) and we compute the number of firms exporting or importing the same main product*country pair as main (or top 2 main) product*country pair. For each year on the period 1996-2004, we calculate the 3 quartiles of the distribution and the table reports the mean of those statistics over the sample period. 'Offshoring' is defined as imports of goods belonging to the same industry as that of the importing firm (see Section 2 for details). 
Table C3: First-stage IV Regressions - excluding China, Germany and the United States

Excluding China, Germany and the US

Exports Offshoring

\begin{tabular}{lcc}
\hline World demand (exports) & $0.142^{* * *}$ & $0.094^{*}$ \\
& $(0.037)$ & $(0.055)$ \\
World supply (imports) & 0.045 & $0.250 * * *$ \\
& $(0.028)$ & $(0.056)$ \\
Controls & Yes & Yes \\
\hline Observations & 21,696 & 21,696 \\
Number of firms & 7,574 & 7,574 \\
Overall R-squared & 0.232 & 0.232 \\
\hline
\end{tabular}

Notes: $* * * \mathrm{p}<0.01, * * \mathrm{p}<0.05, * \mathrm{p}<0.1$. Period: $2005-2009$. Robust standard errors are clustered at the firm level and reported in brackets. Firm-level control variables, year dummies and firm fixed-effects are included in all specifications. 'Exports' is the log of the value of exports. 'Offshoring' is the log of the value of imports of goods belonging to the same industry as that of the importing firm (see Section 2 for details). Product shares entering world demand and world supply are calculated at their overall sample (1996-2004) firm value. The sample consists of firms of our estimating sample but for each firm we exclude from their exports/imports trade flows to/from China, Germany and the US and recalculate exports and imports and the instrumental variables for firms in our estimating sample. 
Table C4: First-stage IV Regressions - Exchange Rates

Non-euro countries

All countries

\begin{tabular}{|c|c|c|c|c|}
\hline & Exports & Offshoring & Exports & Offshoring \\
\hline World demand (exports) & $\begin{array}{c}0.113 * * * \\
(0.035)\end{array}$ & $\begin{array}{c}0.095 * \\
(0.056)\end{array}$ & $\begin{array}{c}0.099 * * * \\
(0.032)\end{array}$ & $\begin{array}{l}0.084 * \\
(0.046)\end{array}$ \\
\hline World supply (imports) & $\begin{array}{c}0.059^{* *} \\
(0.027)\end{array}$ & $\begin{array}{l}0.068 \\
(0.052)\end{array}$ & $\begin{array}{c}0.111 * * * * \\
(0.029)\end{array}$ & $\begin{array}{c}0.196 * * * \\
(0.053)\end{array}$ \\
\hline Exchange rate (exports) & $\begin{array}{c}0.890^{* * * *} \\
(0.165)\end{array}$ & $\begin{array}{l}0.162 \\
(0.256)\end{array}$ & $\begin{array}{c}0.474 * \\
(0.246)\end{array}$ & $\begin{array}{c}-0.666^{* *} \\
(0.331)\end{array}$ \\
\hline Exchange rate (imports) & $\begin{array}{c}-0.299 * * \\
(0.126)\end{array}$ & $\begin{array}{c}0.669 * * * \\
(0.209)\end{array}$ & $\begin{array}{l}-0.130 \\
(0.164)\end{array}$ & $\begin{array}{l}0.498^{*} \\
(0.300)\end{array}$ \\
\hline Controls & Yes & Yes & Yes & Yes \\
\hline Observations & 16,254 & 16,254 & 23,234 & 23,234 \\
\hline Number of firms & 5,960 & 5,960 & 8,100 & 8,100 \\
\hline Overall R-squared & 0.101 & 0.046 & 0.115 & 0.056 \\
\hline
\end{tabular}

Notes: $* * * \mathrm{p}<0.01, * * \mathrm{p}<0.05, * \mathrm{p}<0.1$. Period: $2005-2009$. Robust standard errors are clustered at the firm level and reported in brackets. Firm-level control variables, year dummies and firm fixed-effects are included in all specifications. 'Exports' is the log of the value of exports. 'Offshoring' is the log of the value of imports of goods belonging to the same industry as that of the importing firm (see Section 2 for details). Product shares entering world demand and world supply, Exchange rate (exports) and Exchange rate (imports) are calculated at their overall sample (1996-2004) firm value. The sample 'all countries' consists of our estimating sample (columns 1 and 2) and we build the sample 'Non-euro countries' by recalculating for all firms values of exports and imports and of instruments excluding trade with euro area countries (firms trading only with euro area countries are excluded). 


\begin{tabular}{|c|c|c|c|c|c|c|c|}
\hline & \multicolumn{6}{|c|}{ Excluding observations for which the export/import market share is larger than... } \\
\hline & & \multicolumn{2}{|c|}{$10 \%$} & \multicolumn{2}{|c|}{$15 \%$} & \multicolumn{2}{|c|}{$20 \%$} \\
\hline & & Exports & Offshoring & Exports & Offshoring & Exports & Offshoring \\
\hline $\begin{array}{l}\text { World } \\
\text { (exports) }\end{array}$ & demand & $\begin{array}{c}0.109 * \\
(0.057)\end{array}$ & $\begin{array}{l}0.092 \\
(0.067)\end{array}$ & $\begin{array}{c}0.104 * * \\
(0.048)\end{array}$ & $\begin{array}{l}0.053 \\
(0.050)\end{array}$ & $\begin{array}{l}0.079^{*} \\
(0.044)\end{array}$ & $\begin{array}{l}0.027 \\
(0.049)\end{array}$ \\
\hline $\begin{array}{l}\text { World } \\
\text { (imports) }\end{array}$ & supply & $\begin{array}{c}0.093 * * \\
(0.044)\end{array}$ & $\begin{array}{l}0.135^{*} \\
(0.077)\end{array}$ & $\begin{array}{c}0.101 * * \\
(0.043)\end{array}$ & $\begin{array}{c}0.132 * * \\
(0.064)\end{array}$ & $\begin{array}{c}0.161 * * * \\
(0.041)\end{array}$ & $\begin{array}{c}0.181 * * * \\
(0.065)\end{array}$ \\
\hline Controls & & Yes & Yes & Yes & Yes & Yes & Yes \\
\hline Observati & & 17,299 & 17,299 & 19,777 & 19,777 & 21,055 & 21,055 \\
\hline Number o & ïrms & 6,237 & 6,237 & 7,004 & 7,004 & 7,389 & 7,389 \\
\hline Overall R & quared & 0.459 & 0.459 & 0.495 & 0.495 & 0.500 & 0.500 \\
\hline
\end{tabular}

Notes: $* * * \mathrm{p}<0.01, * * \mathrm{p}<0.05, * \mathrm{p}<0.1$. Period: $2005-2009$. Robust standard errors are clustered at the firm level and reported in brackets. Firm-level control variables, year dummies and firm fixed-effects are included in all specifications. 'Exports' is the log of the value of exports. 'Offshoring' is the log of the value of imports of goods belonging to the same industry as that of the importing firm (see Section 2 for details). Product shares entering world demand and world supply, are calculated at their overall sample (1996-2004) firm value. The sample consists of firms of our estimating sample but we drop product-country observations for which the French export/import market share is less than a given percentage. To calculate the average market share of France in each countryproduct pair, we use the BACI data and define the market share as the percentage of imports by country c of product $p$ that have France as origin (same calculation for exports). Then, for each firm we drop observations productcountry-year for which the export/import market share is larger than a given percentage and, recalculate exports and imports and the instrumental variables. 


\section{Appendix D. Robustness - Wage equation}

Table D1: Firm-level Average Hourly Wage Regressions (All Workers, 2005-2008)

Net hourly wage

Dependent variable (1) (2) (3) (4)

Exports

Offshoring

TFP

Firm size

Capital/labour

Share of high-skilled

workers

Unemployment rate

Temporary contracts

Domestic sales

$0.014 * * *$
$(0.001)$

$0.006 * * *$

(0.001)

(0.001)

\begin{tabular}{|c|c|c|c|}
\hline & & $\begin{array}{c}0.021 * * * \\
(0.003)\end{array}$ & $\begin{array}{c}0.020 * * * \\
(0.003)\end{array}$ \\
\hline & & $\begin{array}{l}-0.004 \\
(0.003)\end{array}$ & $\begin{array}{c}-0.010 * * * \\
(0.003)\end{array}$ \\
\hline & & $\begin{array}{c}0.014 * * * \\
(0.004)\end{array}$ & $\begin{array}{c}0.015 * * * \\
(0.004)\end{array}$ \\
\hline & & $\begin{array}{c}0.425^{*} * * \\
(0.014)\end{array}$ & $\begin{array}{c}0.423 * * * \\
(0.014)\end{array}$ \\
\hline & & $\begin{array}{c}0.001 \\
(0.001)\end{array}$ & $\begin{array}{c}0.001 \\
(0.001)\end{array}$ \\
\hline & & $\begin{array}{c}-0.040 * * * \\
(0.011)\end{array}$ & $\begin{array}{c}-0.040 * * * \\
(0.011)\end{array}$ \\
\hline & & $\begin{array}{l}0.004 * \\
(0.002)\end{array}$ & $\begin{array}{c}0.003 \\
(0.002)\end{array}$ \\
\hline $\begin{array}{c}2.510 * * * \\
(0.028)\end{array}$ & $\begin{array}{c}2.344 * * * \\
(0.027)\end{array}$ & $\begin{array}{c}1.815^{* * *} \\
(0.025)\end{array}$ & $\begin{array}{c}1.794 * * * \\
(0.025)\end{array}$ \\
\hline No & No & Yes & Yes \\
\hline No & Yes & No & Yes \\
\hline 19,045 & 19,045 & 19,045 & 19,045 \\
\hline 7,479 & 7,479 & 7,479 & 7,479 \\
\hline 0.350 & 0.363 & 0.641 & 0.641 \\
\hline
\end{tabular}

$0.021 * * *$

(0.001)

$0.012 * * *$

(0.001)

$0.003 * * *$

(0.001)

$0.007 * * *$

(0.001)

$0.010 * * *$

$(0.001)$

$0.003 * *$

(0.001)
Temporary contracts

Intercept

Controls

IV

Observations

Number of firms

R-squared

0.350

Notes: $* * * \mathrm{p}<0.01, * * \mathrm{p}<0.05, * \mathrm{p}<0.1$; Period: 2005-2008. Robust standard errors are clustered at the firm level and reported in brackets. Year and disaggregate industry-level dummies, random firm-level effects are included in all specifications. 'Net hourly wage' is the log of the average hourly wage in the firm. 'Exports' is the log of the value of exports. 'Offshoring' is the log of the value of imports of goods belonging to the same industry as that of the importing firm (see Section 2 for details). Firm-level controls (size, TFP, capital/labour and domestic sales) are in logs. 
Dependent variable

Net hourly wage

(1)

(2)

(3)

(4)

\begin{tabular}{|c|c|c|c|c|}
\hline Exports & $\begin{array}{c}0.012 * * * \\
(0.001)\end{array}$ & $\begin{array}{c}0.020 * * * \\
(0.001)\end{array}$ & $\begin{array}{c}0.006^{* * *} \\
(0.001)\end{array}$ & $\begin{array}{c}0.010^{* * * *} \\
(0.001)\end{array}$ \\
\hline Imports & $\begin{array}{c}0.010 * * * \\
(0.001)\end{array}$ & $\begin{array}{c}0.014 * * * \\
(0.001)\end{array}$ & $\begin{array}{c}0.004 * * * \\
(0.001)\end{array}$ & $\begin{array}{c}0.003 * * \\
(0.001)\end{array}$ \\
\hline TFP & & & $\begin{array}{c}0.024 * * * \\
(0.003)\end{array}$ & $\begin{array}{c}0.023 * * * \\
(0.003)\end{array}$ \\
\hline Firm size & & & $\begin{array}{l}-0.003 \\
(0.003)\end{array}$ & $\begin{array}{c}-0.008 * * * \\
(0.003)\end{array}$ \\
\hline Capital/labour & & & $\begin{array}{c}0.013 * * * \\
(0.003)\end{array}$ & $\begin{array}{c}0.013 * * * \\
(0.003)\end{array}$ \\
\hline $\begin{array}{l}\text { Share of high-skilled } \\
\text { workers }\end{array}$ & & & $\begin{array}{c}0.381 * * * \\
(0.011)\end{array}$ & $\begin{array}{c}0.379 * * * \\
(0.011)\end{array}$ \\
\hline Unemployment rate & & & $\begin{array}{l}-0.000 \\
(0.001)\end{array}$ & $\begin{array}{l}-0.000 \\
(0.001)\end{array}$ \\
\hline Temporary contracts & & & $\begin{array}{c}-0.035^{* * *} \\
(0.010)\end{array}$ & $\begin{array}{c}-0.035^{* * * *} \\
(0.010)\end{array}$ \\
\hline Domestic sales & & & $\begin{array}{l}0.003 \\
(0.002)\end{array}$ & $\begin{array}{l}0.003 \\
(0.002)\end{array}$ \\
\hline Intercept & $\begin{array}{l}2.471^{* * *} \\
(0.024)\end{array}$ & $\begin{array}{c}2.320 * * * \\
(0.024)\end{array}$ & $\begin{array}{c}1.851^{* * *} \\
(0.024)\end{array}$ & $\begin{array}{c}1.831 * * * \\
(0.024)\end{array}$ \\
\hline Controls & No & No & Yes & Yes \\
\hline IV & No & Yes & No & Yes \\
\hline Observations & 23,269 & 23,269 & 23,269 & 23,269 \\
\hline Number of firms & 8,123 & 8,123 & 8,123 & 8,123 \\
\hline R-squared & 0.353 & 0.362 & 0.632 & 0.632 \\
\hline
\end{tabular}

Notes: $* * * p<0.01, * * p<0.05, * p<0.1$; Period: 2005-2009. Robust standard errors are clustered at the firm level and reported in brackets. Year dummies and firm random effects are included in all specifications. 'Net hourly wage' is the $\log$ of the average hourly wage in the firm. 'Exports' is the log of the value of exports. 'Imports' is the log of the value of imports. Firm-level controls (size, TFP, capital/labour and domestic sales) are in logs. 
Table D3: Firm-level Wage Regressions (by Occupation, 2005-2008)

\begin{tabular}{|c|c|c|c|c|c|c|c|c|}
\hline \multirow[t]{3}{*}{$\begin{array}{l}\text { Dependent } \\
\text { variable }\end{array}$} & \multicolumn{8}{|c|}{ Ln (net hourly wage) } \\
\hline & \multicolumn{2}{|c|}{ Blue collar } & \multicolumn{2}{|c|}{ White-collar } & \multicolumn{2}{|c|}{ Technicians } & \multicolumn{2}{|c|}{ Executives } \\
\hline & OLS & OLS-IV & OLS & OLS-IV & OLS & OLS-IV & OLS & OLS-IV \\
\hline Exports & $\begin{array}{c}0.003 * * * \\
(0.001)\end{array}$ & $\begin{array}{c}0.004 * * * \\
(0.001)\end{array}$ & $\begin{array}{c}0.005^{* * *} * \\
(0.001)\end{array}$ & $\begin{array}{c}0.007 * * * \\
(0.001)\end{array}$ & $\begin{array}{l}0.001 \\
(0.001)\end{array}$ & $\begin{array}{l}0.001 \\
(0.001)\end{array}$ & $\begin{array}{c}0.005^{* * * *} \\
(0.002)\end{array}$ & $\begin{array}{c}0.004 * \\
(0.002)\end{array}$ \\
\hline Offshoring & $\begin{array}{l}0.000 \\
(0.001)\end{array}$ & $\begin{array}{l}-0.001 \\
(0.001)\end{array}$ & $\begin{array}{l}0.000 \\
(0.001)\end{array}$ & $\begin{array}{l}0.000 \\
(0.001)\end{array}$ & $\begin{array}{c}0.003 * * * \\
(0.001)\end{array}$ & $\begin{array}{c}0.004 * * * \\
(0.001)\end{array}$ & $\begin{array}{c}0.004 * * * \\
(0.001)\end{array}$ & $\begin{array}{c}0.008 * * * \\
(0.001)\end{array}$ \\
\hline TFP & $\begin{array}{c}0.015 * * * \\
(0.003)\end{array}$ & $\begin{array}{c}0.015^{* * * *} \\
(0.003)\end{array}$ & $\begin{array}{l}0.006 \\
(0.005)\end{array}$ & $\begin{array}{l}0.005 \\
(0.005)\end{array}$ & $\begin{array}{c}0.024 * * * \\
(0.005)\end{array}$ & $\begin{array}{c}0.024 * * * \\
(0.005)\end{array}$ & $\begin{array}{c}0.031 * * * \\
(0.006)\end{array}$ & $\begin{array}{c}0.030 * * * \\
(0.006)\end{array}$ \\
\hline Firm size & $\begin{array}{c}0.023 * * * \\
(0.003)\end{array}$ & $\begin{array}{c}0.022 * * * \\
(0.003)\end{array}$ & $\begin{array}{c}0.021 * * * \\
(0.003)\end{array}$ & $\begin{array}{c}0.019 * * * \\
(0.003)\end{array}$ & $\begin{array}{c}-0.008 * * \\
(0.003)\end{array}$ & $\begin{array}{c}-0.008 * * \\
(0.004)\end{array}$ & $\begin{array}{c}0.010 * * \\
(0.005)\end{array}$ & $\begin{array}{c}0.009 * \\
(0.005)\end{array}$ \\
\hline $\begin{array}{l}\text { Capital } \\
\text { /labour }\end{array}$ & $\begin{array}{c}0.011 \text { *** } \\
(0.004)\end{array}$ & $\begin{array}{c}0.011 * * * \\
(0.004)\end{array}$ & $\begin{array}{c}0.016^{* * *} \\
(0.005)\end{array}$ & $\begin{array}{c}0.016 * * * \\
(0.005)\end{array}$ & $\begin{array}{c}0.015 * * * \\
(0.005)\end{array}$ & $\begin{array}{c}0.015^{* * *} * \\
(0.005)\end{array}$ & $\begin{array}{l}-0.003 \\
(0.007)\end{array}$ & $\begin{array}{l}-0.003 \\
(0.007)\end{array}$ \\
\hline $\begin{array}{l}\text { Share of } \\
\text { high-skilled } \\
\text { workers }\end{array}$ & $\begin{array}{c}0.068 * * * \\
(0.010)\end{array}$ & $\begin{array}{c}0.068 * * * \\
(0.010)\end{array}$ & $\begin{array}{l}0.009 \\
(0.012)\end{array}$ & $\begin{array}{l}0.008 \\
(0.012)\end{array}$ & $\begin{array}{c}-0.093 * * * \\
(0.013)\end{array}$ & $\begin{array}{c}-0.094 * * * \\
(0.013)\end{array}$ & $\begin{array}{c}-0.040 * * \\
(0.016)\end{array}$ & $\begin{array}{c}-0.043 * * * \\
(0.016)\end{array}$ \\
\hline Unemp. rate & $\begin{array}{l}0.000 \\
(0.001)\end{array}$ & $\begin{array}{l}0.000 \\
(0.001)\end{array}$ & $\begin{array}{l}0.000 \\
(0.001)\end{array}$ & $\begin{array}{l}0.000 \\
(0.001)\end{array}$ & $\begin{array}{l}-0.001 \\
(0.001)\end{array}$ & $\begin{array}{l}-0.001 \\
(0.001)\end{array}$ & $\begin{array}{l}0.001 \\
(0.001)\end{array}$ & $\begin{array}{l}0.001 \\
(0.001)\end{array}$ \\
\hline $\begin{array}{l}\text { Temporary } \\
\text { contracts }\end{array}$ & $\begin{array}{c}-0.047 * * * \\
(0.011)\end{array}$ & $\begin{array}{c}-0.047 * * * \\
(0.011)\end{array}$ & $\begin{array}{c}-0.084 * * * \\
(0.014)\end{array}$ & $\begin{array}{c}-0.085^{* * *} * \\
(0.014)\end{array}$ & $\begin{array}{c}-0.077 * * * \\
(0.015)\end{array}$ & $\begin{array}{c}-0.077 * * * \\
(0.015)\end{array}$ & $\begin{array}{c}-0.049 * * \\
(0.021)\end{array}$ & $\begin{array}{c}-0.050^{* *} \\
(0.021)\end{array}$ \\
\hline $\begin{array}{l}\text { Domestic } \\
\text { sales }\end{array}$ & $\begin{array}{l}0.003 \\
(0.002)\end{array}$ & $\begin{array}{l}0.003 \\
(0.002)\end{array}$ & $\begin{array}{l}0.003 \\
(0.004)\end{array}$ & $\begin{array}{l}0.003 \\
(0.004)\end{array}$ & $\begin{array}{l}0.005 \\
(0.003)\end{array}$ & $\begin{array}{l}0.004 \\
(0.003)\end{array}$ & $\begin{array}{c}0.010 * * \\
(0.004)\end{array}$ & $\begin{array}{c}0.009 * * \\
(0.004)\end{array}$ \\
\hline Intercept & $\begin{array}{c}1.948 * * * \\
(0.025)\end{array}$ & $\begin{array}{c}1.946 * * * \\
(0.025)\end{array}$ & $\begin{array}{c}2.116^{* * * *} \\
(0.027)\end{array}$ & $\begin{array}{c}2.106 * * * \\
(0.027)\end{array}$ & $\begin{array}{c}2.397 * * * \\
(0.035)\end{array}$ & $\begin{array}{c}2.393^{* * * *} \\
(0.035)\end{array}$ & $\begin{array}{c}2.708 * * * \\
(0.039)\end{array}$ & $\begin{array}{c}2.703^{* * *} * \\
(0.040)\end{array}$ \\
\hline IV & No & Yes & No & Yes & No & Yes & No & Yes \\
\hline Observations & 19,045 & 19,045 & 19,045 & 19,045 & 19,045 & 19,045 & 19,045 & 19,045 \\
\hline $\begin{array}{l}\text { Number of } \\
\text { firms } \\
\text { R-squared }\end{array}$ & $\begin{array}{l}7,479 \\
0.414\end{array}$ & $\begin{array}{l}7,479 \\
0.414\end{array}$ & $\begin{array}{l}7,479 \\
0.246\end{array}$ & $\begin{array}{l}7,479 \\
0.247\end{array}$ & $\begin{array}{l}7,479 \\
0.186\end{array}$ & $\begin{array}{l}7,479 \\
0.186\end{array}$ & $\begin{array}{l}7,479 \\
0.189\end{array}$ & $\begin{array}{l}7,479 \\
0.189\end{array}$ \\
\hline
\end{tabular}

Notes: $* * * p<0.01, * * p<0.05, * p<0.1$; Period: 2005-2008. Robust standard errors are clustered at the firm level and reported in brackets. Year and disaggregate industry-level dummies, random firm-level effects are included in all specifications. 'Net hourly wage' is the log of the average hourly wage by job occupation in the firm. 'Exports' is the $\log$ of the value of exports. 'Offshoring' is the log of the value of imports of goods belonging to the same industry as that of the importing firm (see Section 2 for details). Firm-level controls (size, TFP, capital/labour and domestic sales) are in logs. 
Table D4: Firm-level Wage Regressions (by Occupation) (2005-2009) - Total Imports

\begin{tabular}{|c|c|c|c|c|c|c|c|c|}
\hline \multirow[t]{3}{*}{$\begin{array}{l}\text { Dependent } \\
\text { variable }\end{array}$} & \multicolumn{8}{|c|}{ Net hourly wage } \\
\hline & \multicolumn{2}{|c|}{ Blue collar } & \multicolumn{2}{|c|}{ White-collar } & \multicolumn{2}{|c|}{ Technicians } & \multicolumn{2}{|c|}{ Executives } \\
\hline & OLS & OLS-IV & OLS & OLS-IV & OLS & OLS-IV & OLS & OLS-IV \\
\hline Exports & $\begin{array}{c}0.004 * * * \\
(0.001)\end{array}$ & $\begin{array}{c}0.005 * * * \\
(0.001)\end{array}$ & $\begin{array}{c}0.004 * * * \\
(0.001)\end{array}$ & $\begin{array}{c}0.006 * * * \\
(0.001)\end{array}$ & $\begin{array}{l}0.002^{*} \\
(0.001)\end{array}$ & $\begin{array}{l}0.003 * \\
(0.001)\end{array}$ & $\begin{array}{l}0.003^{*} \\
(0.002)\end{array}$ & $\begin{array}{c}0.002 \\
(0.002)\end{array}$ \\
\hline Imports & $\begin{array}{l}-0.001 \\
(0.001)\end{array}$ & $\begin{array}{c}-0.003^{* *} \\
(0.001)\end{array}$ & $\begin{array}{c}0.002 \\
(0.001)\end{array}$ & $\begin{array}{c}0.001 \\
(0.001)\end{array}$ & $\begin{array}{c}0.004 * * * \\
(0.001)\end{array}$ & $\begin{array}{c}0.003^{* *} \\
(0.002)\end{array}$ & $\begin{array}{c}0.008 * * * \\
(0.002)\end{array}$ & $\begin{array}{c}0.012 * * * \\
(0.002)\end{array}$ \\
\hline TFP & $\begin{array}{c}0.021 * * * \\
(0.004)\end{array}$ & $\begin{array}{c}0.022 * * * \\
(0.004)\end{array}$ & $\begin{array}{c}0.011 * * \\
(0.004)\end{array}$ & $\begin{array}{c}0.011 * * \\
(0.004)\end{array}$ & $\begin{array}{c}0.029 * * * \\
(0.004)\end{array}$ & $\begin{array}{c}0.029 * * * \\
(0.004)\end{array}$ & $\begin{array}{c}0.031^{* * *} \\
(0.005)\end{array}$ & $\begin{array}{c}0.030 * * * \\
(0.005)\end{array}$ \\
\hline Firm size & $\begin{array}{c}0.020 * * * \\
(0.003)\end{array}$ & $\begin{array}{c}0.020 * * * \\
(0.003)\end{array}$ & $\begin{array}{c}0.020 * * * \\
(0.003)\end{array}$ & $\begin{array}{c}0.018 * * * \\
(0.003)\end{array}$ & $\begin{array}{c}-0.008 * * \\
(0.003)\end{array}$ & $\begin{array}{c}-0.008 * * \\
(0.003)\end{array}$ & $\begin{array}{c}0.012 * * * \\
(0.004)\end{array}$ & $\begin{array}{c}0.011 * * \\
(0.004)\end{array}$ \\
\hline Capital/labour & $\begin{array}{c}0.009 * * \\
(0.004)\end{array}$ & $\begin{array}{c}0.009 * * \\
(0.004)\end{array}$ & $\begin{array}{c}0.016^{* * * *} \\
(0.005)\end{array}$ & $\begin{array}{c}0.016 * * * \\
(0.005)\end{array}$ & $\begin{array}{c}0.012 * * \\
(0.005)\end{array}$ & $\begin{array}{c}0.012 * * \\
(0.005)\end{array}$ & $\begin{array}{l}-0.002 \\
(0.007)\end{array}$ & $\begin{array}{l}-0.002 \\
(0.007)\end{array}$ \\
\hline $\begin{array}{l}\text { Share of high- } \\
\text { skilled workers }\end{array}$ & $\begin{array}{c}0.029 * * * \\
(0.009)\end{array}$ & $\begin{array}{c}0.029 * * * \\
(0.009)\end{array}$ & $\begin{array}{l}-0.007 \\
(0.010)\end{array}$ & $\begin{array}{l}-0.008 \\
(0.010)\end{array}$ & $\begin{array}{c}-0.118 * * * \\
(0.012)\end{array}$ & $\begin{array}{c}-0.118^{* * *} \\
(0.012)\end{array}$ & $\begin{array}{c}-0.051 * * * \\
(0.014)\end{array}$ & $\begin{array}{c}-0.052 * * * \\
(0.014)\end{array}$ \\
\hline Unemp. rate & $\begin{array}{c}-0.002 * * * \\
(0.001)\end{array}$ & $\begin{array}{c}-0.002 * * * \\
(0.001)\end{array}$ & $\begin{array}{l}-0.000 \\
(0.001)\end{array}$ & $\begin{array}{l}-0.000 \\
(0.001)\end{array}$ & $\begin{array}{l}-0.001 \\
(0.001)\end{array}$ & $\begin{array}{l}-0.001 \\
(0.001)\end{array}$ & $\begin{array}{c}0.001 \\
(0.001)\end{array}$ & $\begin{array}{c}0.001 \\
(0.001)\end{array}$ \\
\hline $\begin{array}{l}\text { Temporary } \\
\text { contracts }\end{array}$ & $\begin{array}{c}-0.049 * * * \\
(0.011)\end{array}$ & $\begin{array}{c}-0.048 * * * \\
(0.011)\end{array}$ & $\begin{array}{c}-0.072 * * * \\
(0.014)\end{array}$ & $\begin{array}{c}-0.072 * * * \\
(0.014)\end{array}$ & $\begin{array}{c}-0.077 * * * \\
(0.015)\end{array}$ & $\begin{array}{c}-0.077 * * * * \\
(0.015)\end{array}$ & $\begin{array}{c}-0.037 * \\
(0.020)\end{array}$ & $\begin{array}{c}-0.038^{*} \\
(0.020)\end{array}$ \\
\hline Domestic sales & $\begin{array}{l}0.004^{*} \\
(0.002)\end{array}$ & $\begin{array}{c}0.005^{* *} * \\
(0.002)\end{array}$ & $\begin{array}{l}0.001 \\
(0.004)\end{array}$ & $\begin{array}{c}0.001 \\
(0.004)\end{array}$ & $\begin{array}{c}0.003 \\
(0.003)\end{array}$ & $\begin{array}{c}0.003 \\
(0.003)\end{array}$ & $\begin{array}{l}0.008^{*} \\
(0.004)\end{array}$ & $\begin{array}{l}0.007 * \\
(0.004)\end{array}$ \\
\hline Intercept & $\begin{array}{c}1.991 * * * \\
(0.024)\end{array}$ & $\begin{array}{c}1.999 * * * \\
(0.024)\end{array}$ & $\begin{array}{c}2.139 * * * \\
(0.026)\end{array}$ & $\begin{array}{c}2.131 * * * \\
(0.026)\end{array}$ & $\begin{array}{c}2.355^{* * * *} \\
(0.032)\end{array}$ & $\begin{array}{c}2.356 * * * \\
(0.033)\end{array}$ & $\begin{array}{c}2.663 * * * \\
(0.039)\end{array}$ & $\begin{array}{c}2.650 * * * \\
(0.040)\end{array}$ \\
\hline IV & No & Yes & No & Yes & No & Yes & No & Yes \\
\hline Observations & 23,269 & 23,269 & 23,269 & 23,269 & 23,269 & 23,269 & 23,269 & 23,269 \\
\hline $\mathrm{Nr}$ of firms & 8,123 & 8,123 & 8,123 & 8,123 & 8,123 & 8,123 & 8,123 & 8,123 \\
\hline R-squared & 0.416 & 0.416 & 0.258 & 0.258 & 0.185 & 0.185 & 0.187 & 0.188 \\
\hline
\end{tabular}

Notes: *** $\mathrm{p}<0.01, * * \mathrm{p}<0.05, * \mathrm{p}<0.1$; Period: 2005-2009. Robust standard errors are clustered at the firm level and reported in brackets. Year and disaggregate industry-level dummies, random firm-level effects are included in all specifications. 'Net hourly wage' is the log of the average hourly wage by occupation in the firm. 'Exports' is the $\log$ of the value of exports. 'Imports' is the log of the value of imports. Firm-level controls (size, TFP, capital/labour and domestic sales) are in logs. 
Table D5: Firm-level Wage Regressions by Bargaining Regime and by Occupation (2005-2009) Total Imports

\begin{tabular}{|c|c|c|c|}
\hline Firm wage agreement & No & No & Yes \\
\hline Industry wage agreement & No & Yes & - \\
\hline \multicolumn{4}{|l|}{ Total } \\
\hline$\overline{\text { Exports }}$ & $\begin{array}{c}0.010 * * * \\
(0.002)\end{array}$ & $\begin{array}{c}0.010 * * * \\
(0.001)\end{array}$ & $\begin{array}{c}0.016^{* * * *} \\
(0.003)\end{array}$ \\
\hline Imports & $\begin{array}{l}-0.001 \\
(0.003)\end{array}$ & $\begin{array}{c}0.004 * * \\
(0.001)\end{array}$ & $\begin{array}{l}-0.002 \\
(0.003)\end{array}$ \\
\hline R-Squared & 0.625 & 0.604 & 0.735 \\
\hline \multicolumn{4}{|l|}{ Blue-collar workers } \\
\hline Exports & $\begin{array}{c}0.005^{* *} \\
(0.002)\end{array}$ & $\begin{array}{c}0.004 * * * \\
(0.001)\end{array}$ & $\begin{array}{c}0.011 * * * \\
(0.003)\end{array}$ \\
\hline Imports & $\begin{array}{c}-0.005^{* *} \\
(0.003)\end{array}$ & $\begin{array}{c}-0.004 * * \\
(0.001)\end{array}$ & $\begin{array}{l}-0.002 \\
(0.004)\end{array}$ \\
\hline R-Squared & 0.424 & 0.346 & 0.538 \\
\hline \multicolumn{4}{|l|}{ White-collar workers } \\
\hline Exports & $\begin{array}{c}0.007 * * * * \\
(0.003)\end{array}$ & $\begin{array}{c}0.006 * * * \\
(0.001)\end{array}$ & $\begin{array}{l}0.005 \\
(0.004)\end{array}$ \\
\hline Imports & $\begin{array}{c}-0.006^{* * *} \\
(0.003)\end{array}$ & $\begin{array}{c}0.002 \\
(0.002)\end{array}$ & $\begin{array}{l}0.006^{*} \\
(0.004)\end{array}$ \\
\hline R-Squared & 0.276 & 0.202 & 0.365 \\
\hline \multicolumn{4}{|l|}{ Technicians and supervisors } \\
\hline Exports & $\begin{array}{c}0.005 \\
(0.003)\end{array}$ & $\begin{array}{c}0.002 \\
(0.002)\end{array}$ & $\begin{array}{c}0.009 * * * \\
(0.003)\end{array}$ \\
\hline Imports & $\begin{array}{l}0.001 \\
(0.003)\end{array}$ & $\begin{array}{c}0.002 \\
(0.002)\end{array}$ & $\begin{array}{l}-0.001 \\
(0.004)\end{array}$ \\
\hline R-Squared & 0.208 & 0.167 & 0.338 \\
\hline \multicolumn{4}{|l|}{ Executives } \\
\hline Exports & $\begin{array}{l}0.004 \\
(0.004)\end{array}$ & $\begin{array}{l}-0.000 \\
(0.002)\end{array}$ & $\begin{array}{c}0.012 * * * \\
(0.004)\end{array}$ \\
\hline Imports & $\begin{array}{c}0.003 \\
(0.005)\end{array}$ & $\begin{array}{c}0.015 * * * \\
(0.002)\end{array}$ & $\begin{array}{c}0.003 \\
(0.004)\end{array}$ \\
\hline R-Squared & 0.192 & 0.163 & 0.315 \\
\hline Observations & 3,509 & 14,683 & 5,077 \\
\hline Number of firms & 2,556 & 6,124 & 1,293 \\
\hline
\end{tabular}

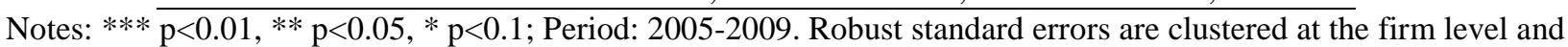
reported in brackets. Year and disaggregate industry-level dummies, random firm-level effects and firm-level controls are included in all specifications. 'Net hourly wage' is the log of the average hourly wage by occupation in the firm. 'Exports' is the log of the value of exports. 'Imports' is the log of the value of imports. The category 'Firm-level wage agreement' is defined according to the frequency of firm-level wage agreements for a given firm, 'Yes' corresponds to firms that agree on wages more than $20 \%$ of years over the period 2002-2009, 'No' less than $20 \%$ of wage agreements over the same period. The category 'Industry-level wage agreement' means that a firm is covered by an industry-wage agreement in a given year. 
Table D6: Firm-level Average Hourly Wage Regressions: by Bargaining Regime and Occupation

Dependent variable

Net hourly wage

\begin{tabular}{|c|c|c|c|c|c|c|}
\hline & \multicolumn{2}{|c|}{$\begin{array}{l}\text { Existence of an } \\
\text { agreement }\end{array}$} & \multicolumn{2}{|c|}{$\begin{array}{l}\text { Agreement } \\
\text { on wages }\end{array}$} & \multicolumn{2}{|c|}{$\begin{array}{l}\text { Agreement on topics other } \\
\text { than wages }\end{array}$} \\
\hline & No & Yes & No & Yes & No & Yes \\
\hline \multicolumn{7}{|l|}{ Blue-collar workers } \\
\hline Exports & $\begin{array}{l}0.003 * * * \\
(0.001)\end{array}$ & $\begin{array}{l}0.010 * * * \\
(0.003)\end{array}$ & $\begin{array}{l}0.003 * * * \\
(0.001)\end{array}$ & $\begin{array}{l}0.011 * * * \\
(0.003)\end{array}$ & $\begin{array}{l}0.004 * * * \\
(0.001)\end{array}$ & $\begin{array}{c}0.009 * * \\
(0.004)\end{array}$ \\
\hline Offshoring & $\begin{array}{c}-0.002 * * \\
(0.001)\end{array}$ & $\begin{array}{l}-0.001 \\
(0.002)\end{array}$ & $\begin{array}{l}-0.001 \\
(0.001)\end{array}$ & $\begin{array}{l}-0.001 \\
(0.002)\end{array}$ & $\begin{array}{c}-0.001 * \\
(0.001)\end{array}$ & $\begin{array}{l}0.001 \\
(0.003)\end{array}$ \\
\hline R-squared & 0.587 & 0.731 & 0.598 & 0.736 & 0.597 & 0.743 \\
\hline \multicolumn{7}{|c|}{ White-collar workers } \\
\hline Exports & $\begin{array}{c}0.006 * * * \\
(0.001)\end{array}$ & $\begin{array}{l}0.006^{*} \\
(0.003)\end{array}$ & $\begin{array}{c}0.006 * * * \\
(0.001)\end{array}$ & $\begin{array}{l}0.006^{*} \\
(0.003)\end{array}$ & $\begin{array}{l}0.007 * * * \\
(0.001)\end{array}$ & $\begin{array}{l}0.002 \\
(0.004)\end{array}$ \\
\hline Offshoring & $\begin{array}{l}-0.001 \\
(0.001)\end{array}$ & $\begin{array}{l}0.002 \\
(0.002)\end{array}$ & $\begin{array}{l}-0.001 \\
(0.001)\end{array}$ & $\begin{array}{l}0.003 \\
(0.002)\end{array}$ & $\begin{array}{r}-0.000 \\
(0.001)\end{array}$ & $\begin{array}{l}0.002 \\
(0.003)\end{array}$ \\
\hline R-squared & 0.194 & 0.359 & 0.206 & 0.364 & 0.214 & 0.362 \\
\hline \multicolumn{7}{|c|}{ Technicians and engineers } \\
\hline Exports & $\begin{array}{l}0.002 \\
(0.001)\end{array}$ & $\begin{array}{c}0.006 * * \\
(0.003)\end{array}$ & $\begin{array}{l}0.002 \\
(0.001)\end{array}$ & $\begin{array}{c}0.007 * * \\
(0.003)\end{array}$ & $\begin{array}{l}0.002 \\
(0.001)\end{array}$ & $\begin{array}{l}0.004 \\
(0.004)\end{array}$ \\
\hline Offshoring & $\begin{array}{c}0.004 * * * \\
(0.001)\end{array}$ & $\begin{array}{l}0.003 \\
(0.002)\end{array}$ & $\begin{array}{c}0.004 * * * \\
(0.001)\end{array}$ & $\begin{array}{l}0.003 \\
(0.002)\end{array}$ & $\begin{array}{l}0.004 * * * \\
(0.001)\end{array}$ & $\begin{array}{l}0.006 * * * \\
(0.002)\end{array}$ \\
\hline R-squared & 0.157 & 0.336 & 0.162 & 0.340 & 0.166 & 0.396 \\
\hline \multicolumn{7}{|l|}{ Executives } \\
\hline Exports & $\begin{array}{l}0.002 \\
(0.002)\end{array}$ & $\begin{array}{c}0.011 * * * \\
(0.003)\end{array}$ & $\begin{array}{l}0.002 \\
(0.002)\end{array}$ & $\begin{array}{c}0.011 * * * \\
(0.004)\end{array}$ & $\begin{array}{l}0.003 \\
(0.002)\end{array}$ & $\begin{array}{c}0.009 * * \\
(0.004)\end{array}$ \\
\hline Offshoring & $\begin{array}{c}0.007 * * * \\
(0.002)\end{array}$ & $\begin{array}{c}0.006 * * \\
(0.003)\end{array}$ & $\begin{array}{c}0.008 * * * \\
(0.001)\end{array}$ & $\begin{array}{c}0.006^{* *} \\
(0.003)\end{array}$ & $\begin{array}{c}0.007 * * * \\
(0.001)\end{array}$ & $\begin{array}{c}0.007 * * \\
(0.003)\end{array}$ \\
\hline $\mathrm{R}$-squared & 0.148 & 0.308 & 0.155 & 0.317 & 0.156 & 0.337 \\
\hline Observations & 17,479 & 5,790 & 18,192 & 5,077 & 19,371 & 3,898 \\
\hline Number of firms & 6,624 & 1,499 & 6,830 & 1,293 & 7,107 & 1,016 \\
\hline
\end{tabular}

Notes: $* * * \mathrm{p}<0.01, * * \mathrm{p}<0.05, * \mathrm{p}<0.1$; Period: 2005-2009. Robust standard errors are clustered at the firm level and reported in brackets. Year and disaggregate industry-level dummies, random firm-level effects and firm-level control variables $(\mathrm{TFP}, \ldots)$ are included in all specifications. 'Net hourly wage' is the log of the average hourly wage by occupation in the firm. 'Exports' is the log of the value of exports. 'Offshoring' is the log of the value of imports of goods belonging to the same industry as that of the importing firm (see Section 2 for details). The existence of agreements variable is defined as a dummy variable equal to one if a firm frequently signs agreements on any topic (wages + other topics) (columns 1 and 2). Columns 3 and 4 compare firms that frequently agree on wages and firms that do not frequently agree on wages (our baseline result). Columns 5 and 6 compare firms that frequently agree on other topics than wages and firms that do not frequently agree on other topics. 